\title{
Structure-based virtual screening suggests inhibitors of 3- Chymotrypsin-Like Protease of SARS-CoV-2 from Vernonia amygdalina and Occinum gratissimum
}

Gideon A. Gyebi

Bingham University, Karu, Nasarawa, Nigeria https://orcid.org/0000-0002-1945-1739

Abdo A. Elfiky ( $\square$ abdo@sci.cu.edu.eg )

Cairo University, Giza Egypt

Oludare M. Ogunyemi ( $\nabla$ omogunyemi1@gmail.com )

Salem University, Nigeria https://orcid.org/0000-0002-9956-3860

Ibrahim M. Ibrahim

Cairo University, Giza Egypt

Adegbenro P. Adegunloye

University of llorin, Ilorin, Nigeria

Joseph 0. Adebayo

University of Ilorin, Ilorin, Nigeria

Charles O. Olaiya

University of Ibadan, Ibadan, Nigeria https://orcid.org/0000-0003-3088-1067

Joshua Ocheje

Salem University, Nigeria

Mercy M Fabusiwa

Salem University Nigeria

\section{Research Article}

Keywords: Coronavirus, Phytochemicals, molecular docking, ADMET SAR, molecular dynamics simulation

Posted Date: March 9th, 2021

DOI: https://doi.org/10.21203/rs.3.rs-301445/v1

License: (c) This work is licensed under a Creative Commons Attribution 4.0 International License. Read Full License

Version of Record: A version of this preprint was published at Computers in Biology and Medicine on September 1st, 2021. See the published version at https://doi.org/10.1016/j.compbiomed.2021.104671. 


\section{Abstract}

An in-house library of 173 phytocompound structures from Vernonia amygdalina and Occinum gratissimum was screened against the active region of 3-Chymotrypsin-Like Protease (3CL $\left.{ }^{\text {pro }}\right)$ of SARS-CoV-2 in silico. Based on docking scores and reference inhibitors, a hit- list of 21 phytocompounds, with binding energies ranging from - 7.2 to -8.0 $\mathrm{kcal} / \mathrm{mol}$, was initially generated. Further docking against the $3 \mathrm{CL}^{\text {pro }}$ of related coronaviruses (SARS-CoV and MERSCoV), docking to 5 different representative conformations generated from the cluster analysis of SARS-CoV-2 3CL molecular dynamics simulation (MDS) trajectories, and in silico drug-likeness analyses, revealed two drug-like terpenoid structures as promising non-covalent inhibitors of SARS-CoV-2 $3 \mathrm{CL}^{\text {Pro }}$ viz: neoandrographolide and vernolide. These terpenoid structures are accommodated within the substrate-binding pocket, and interacted with the catalytic dyad, the oxyanion loop (residues 138-145), and the S1/S2 subsites of the enzyme active site. With the aid of an array of hydrogen bonds and hydrophobic interactions with residues 142-145, these phytocompounds may stabilize the conformation of the flexible oxyanion loop; and thereby interfere with the tetrahedral oxyanion intermediate formation during proteolytic cleavage. Molecular dynamics simulation and binding free energy calculation further revealed that the terpenoid-enzyme complexes exhibit strong interactions and structural stability, which could be adapted for experimental models.

\section{Introduction}

The severe acute respiratory syndrome coronavirus 2 (SARS-CoV-2) is responsible for the current global health crisis called coronavirus disease 2019 (COVID-19). Coronavirus infections have been life-threatening and difficult to treat due to their rapid outbreak, ease of adaptation, emergence of new and resistant viral strains and the ineffectiveness of antibiotics [1]. SARS-CoV-2 was shown to share a close genome sequence with SARS-CoV and MERS-CoV, mostly in the open reading frame a (ORF1a) [2]. Hence, SARS-CoV-2 has been clustered with beta-coronavirus genera, including SARS and SARS-like coronaviruses. The genome of SARS-CoV-2 contains a positive-sense, single-stranded RNA of about $30 \mathrm{~kb}$ size [3]. It is made up of a number of ORFs, with the first ORF being the largest, representing about $66 \%$ of the genome [4]. Upon cell entry, the genome of the virus is emptied into host cell. The translation of the genomic content by the host's ribosomes yields structural and non-structural proteins [5]. The first ORF results in about 16 non-structural proteins (nsps), including the non-structural protein 5 (nsp5), also called 3-Chymotrypsin-like protease (3CL ${ }^{\text {pro }}$ ). The protease $3 \mathrm{CL}^{\text {pro }}$ consists of 306 amino acid residues, ranging from amino acid 3264 to amino acid 3569 of the polyprotein $1 \mathrm{ab}$.

The 3-Chymotrypsin-like protease $\left(3 \mathrm{CL}^{\mathrm{pro}}\right)$ is a cysteine protease that facilitates the proteolytic processing of the viral polyproteins to yield functional proteins essential for the packaging of new virions [6]. It is one of the most important components of viral replication as it cleaves the replicase polyprotein after its translation at 11 different sites releasing most of the functional protein components of the replicase-transcriptase complex, hence it is also known as main protease of coronaviruses [7]. Amino acid sequence alignments of this protease revealed that, while SARS-CoV-2 3CL ${ }^{\text {pro }}$ had $~ 96 \%$ sequence identity with the previous SARS-CoV 3CL ${ }^{\text {pro, }}$, it has only 50\% sequence identity with MERS-CoV $3 \mathrm{CL}^{\text {pro }}[8]$. Its substrate specificity is primarily defined by the residues at the $\mathrm{P} 1, \mathrm{P} 1{ }^{\prime}$ and $\mathrm{P} 2$ positions of the peptide substrate. These positions are highly conserved in all coronaviruses in particular the presence of glutamine at the P1 position (N-terminus of the scissile bond) of the substrate is strictly required for 3CLpro binding across all coronaviruses [7]. Inhibition of $3 \mathrm{CL}^{\text {pro }}$ by compounds is not expected to interfere with human proteases since the protease has no homologue in human [6]. This coupled with its critical role in the survival, replication and infectivity of SARS-CoV-2, it is an attractive drug target [9]. Inhibitors of this protease such as lopinavir and ritonavir, used for the treatment of HIV are reported for their potential use against COVID-19 [10], though with some uncertainties. 
While specific drugs and vaccines targeting important proteins in SARS-CoV-2 are still under development, considerable volume of scientific evidence suggest that phytochemicals with antiviral activities can be deployed against SARS-CoV-2 [11-13]. Studies have revealed that such phytochemicals from indigenous herbs and medicinal plants may inhibit replication of coronaviruses, especially SARS-CoV-2 [14-16]. Vernonia amygdalina Del., (African tea leaf) is a small shrub growing predominantly in tropical Africa widely used for culinary purposes $[17,18]$. This plant has been used earlier in Western Africa against several viral diseases $[19,20]$. Occinum gratissimum known as African basil, a culinary herb with strong spicy flavour widely consumed in West Africa, is known to exhibit a wide range of biological activities [21]. In vitro studies showed that its leaf extract inhibited HIV-1 and HIV-2 replication with antiviral indices of 110 [22]. These culinary herbs have been suggested as potential bioresources against COVID-19 [23]. Other culinary herbs, such as Aframomum melagueta and Piper guineense, are also well documented for antiviral activities [24].

Structure-based virtual screening (SBVS) has been widely employed to search chemical compound libraries towards bioprospecting novel bioactive molecules against viral drug targets in the on-going campaign against coronavirus pandemic $[25,26]$. It is a fast, environmentally sound, and cost effective approach used in early-stage of drug discovery process [27]. A dataset of compounds is docked into the binding site of the three-dimensional (3D) structure of the biological target obtained from X-ray, NMR, or computational modelling, in order to select a subset of these compounds based on the predicted binding scores for further biological evaluation. Identification and documentation of antiviral structures from widely consumed African antiviral culinary herbs and spices such as Vernonia amygdalina and Occinum gratissimum may help to support the current drive towards developing safe, accessible and economically feasible antiviral preparations to be used as home-grown preventive nutraceuticals, food supplements, and antiviral drugs against the pandemic. Therefore, this study was carried out to screen an in-house library of 173 compounds from Vernonia amygdalina and Occinum gratissimum for druggable phytochemicals with direct interactions with the active site of SARS-CoV-2 3CL ${ }^{\text {pro }}$ in silico.

\section{Materials And Methods}

\subsection{Retrieval and preparation of protein structure for molecular docking}

The recently published three-dimensional structure of 3CL ${ }^{\text {pro }}$ of SARS-CoV-2 (PDBID: 6y84), and those of SARS-CoV (PDB ID: 2DUC) and MERS-CoV (PDB ID: 2YNA), were retrieved from the Protein Data Bank (http://www.rcsb.org). All the crystal structures were prepared by removing existing ligands and water molecules, while missing hydrogen atoms were added using Autodock version 4.2 programs (Scripps Research Institute, La Jolla, CA).

\subsection{Ligand preparation for molecular docking}

Structure Data Format structures of the reference inhibitors (Lopinavir and Ritonavir) of $3 \mathrm{CL}^{\text {pro }}$ and 173 bioactive phytocompounds derived from two West African culinary herbs (Vernonia amygdalina and Occinum gratissimum) were retrieved from the PubChem database (www.pubchem.ncbi.nlm.nih.gov). They were converted to mol2 chemical format using Open babel [28], while compounds that were not available on the database were drawn with ChemDraw version 19, and converted to mol2 chemical format. Polar hydrogen charges of the Gasteiger-type were assigned to atoms, while the non-polar hydrogen molecules were merged with the carbons and the internal degrees of freedom and torsions were set to zero. Ligand molecules were further converted to the dockable PDBQT format using AutoDock Tools.

\subsection{Molecular docking study}

\subsubsection{Active site targeted molecular docking of phytochemicals}


An active site targeted virtual screening with the phytochemicals and reference inhibitors against SARS-CoV-2 3CL ${ }^{\text {ro }}$ was initially performed using AutoDock Vina in PyRx 0.8 [29]. Based on the docking scores, binding poses and interaction in the catalytic site, a hit-list of 21 phytochemicals was defined. The top docked compounds were further docked into the active sites of $3 \mathrm{CL}^{\text {pro }}$ of SARS-CoV and MERS-CoV. The ligands were imported and energy minimization was performed with OpenBabel [28] incorporated into PyRx 0.8. The Universal Force Field (UFF) was used as the energy minimization parameter and conjugate gradient descent as the optimization algorithm. The active sites of the three proteins as defined by the grid boxes that were used for docking studies are presented in Table 1. All the other parameters were kept as default. The molecular interactions were viewed with Discovery Studio Visualizer version 16.

Table 1

Binding site coordinates of 3-Chymotrypsin-like protease of related Coronaviruses

\begin{tabular}{|llll|}
\hline Dimensions & $\begin{array}{l}\text { SARS-CoV-2 } \\
(\AA)\end{array}$ & $\begin{array}{l}\text { SARS-CoV } \\
(\AA)\end{array}$ & $\begin{array}{l}\text { MERS-CoV } \\
(\AA)\end{array}$ \\
\hline center_x & 11.06 & 44.40 & 29.28 \\
center_y & 4.06 & 14.71 & 44.91 \\
\hline center_z & 14.93 & 11.43 & 16.60 \\
Size x & 18.50 & 23.16 & 20.89 \\
\hline Size y & 23.02 & 18.95 & 18.37 \\
Size z & 23.02 & 21.66 & 20.47 \\
\hline
\end{tabular}

\subsection{Molecular dynamics simulation}

The structure of SARS-CoV-2 3CL ${ }^{\text {pro }}$ was downloaded from the Protein Data Bank with code 6 Y84 [30, 31]. The structure was subjected to a 100 ns production run at the NVT ensemble (normal volume and temperature with a constant number of atoms) molecular dynamics simulation (MDS). Before the production run, the system was subjected to minimization for 10000 steps using a conjugate gradient algorithm. CHARMM 36 force field was used in the MDS using the Nanoscale Molecular Dynamics (NAMD 2.13) software [32, 33]. Visualizing Molecular Dynamics (VMD 1.9.3) software was used to prepare the input files and analyze the output trajectories [34]. A water box was added to the protein system after adding the missing Hydrogen atoms and removing any ligands. TIP3P water model was used to resemble the added water box, with $10 \AA$ padding, for the periodic boundary condition to be applied [35]. Nose-Hoover Langevin piston was used to control the pressure at 1.01325 bar. In contrast, Langevin dynamics controlled the system's temperature at the physiological value. The temperature, $\mathrm{pH}$, and salt concentration were set at the physiological values $(310 \mathrm{~K}, 7.0$, and $0.154 \mathrm{M} \mathrm{NaCl}$, respectively) during the simulation period. The time step was set at its default two fs with SHAKE approximation in action. Subsequently, cluster analysis of the trajectories was performed using the UCSF Chimera software using its default values [36]. A representative conformation from each cluster was used in the in-depth docking experiment as discussed below.

The best two complexes from the docking experiment (3CLpro-Neoandrographolide and 3CLpro-vernolide complexes) were chosen for Molecular Dynamic Simulation (MDS) using NAMD 2.13. The necessary MDS files were generated using CHARMM-GUI [37-39] while setting the salt concentration and temperature to $0.154 \mathrm{NaCl}$ and $310 \mathrm{~K}$, respectively, to mimic the physiological conditions. Before running the production run of $25 \mathrm{~ns}$, the system was minimized for 10000 steps in a constant number of atoms, constant volume, and constant temperature (NVT) ensemble using a conjugate 
gradient algorithm then equilibrated in a constant number of atoms, constant pressure, and constant temperature (NPT) ensemble for one ns. The pressure was controlled by the Nose-Hoover Langevin piston set to atmospheric pressure (1.01325 bar), while the temperature was controlled by Langevin dynamics. The force field used was the CHARMM36 force field.

Binding affinity was calculated using Molecular Mechanics Generalized Born Surface Area (MM-GBSA) utilizing MMPBSA.py script implemented in Amber tools 17 [40, 41]. All frames (250 frames) were used in the calculation with salt concentration set to $0.154 \mathrm{Mol}$, while the rest of the settings were left as default.

\subsubsection{Molecular docking of the top ten phytochemicals todifferent clusters from molecular dynamics trajectories}

Five different coordinates of $3 \mathrm{CL}^{\text {pro }}$ after cluster analysis of the MDS trajectories were used to dock the best ten compounds (vernolide, vernomygdin, 11, 13-dihydrovernodalin, neoandrographolide, vernomenin, myricetin, chicoric acid, luteolin, rosmarinic acid, and isorhamnetin) along with the positive controls (ritonavir and lopinavir) using AutoDock Vina software [29, 42]. The 3D structures of these ten were generated using the Avogadro software [43], while the Universal Force Field (UFF) was employed to optimize it using the steepest descent algorithm with energies $(806,1046,2015,1740$, 394, 741, 428, 388, 272, 241, 213, and 875 KJ/mol, respectively) [43-45]. The Protein-Ligand Interaction Profiler (PLIP) web server and PyMOL 2.4 software were utilized to analyze the docking complexes [46].

\subsection{In silico Physicochemical Properties and ADMET study}

The top ranked compounds based on their binding affinity and docked poses with the 5 different representative structures were subjected to various drug-likeness and ADMET filtering analysis. The drug-likeness analysis which includes Lipinski, Veber, Ghose, Egan and Muegge were performed on the SwissADME

(http://www.swissadme.ch/index.php) webserver. [47], while the predicted Absorption, Distribution, Metabolism, Excretion and toxicity (ADME/tox) study was analysed using the SuperPred webserver

(http://Immd.ecust.edu.cn/admetsar1/predict/) [48]. The SDF file and canonical SMILES of the compounds were downloaded from PubChem Database or copied from ChemDraw to calculate ADMET properties using default parameters.

\section{Results And Discussion}

\subsection{Screening of phytochemicals against the active site of SARS-CoV-2 3CL pro}

Structure- based virtual screening attempts to predict the best mode of interaction between two molecules to form a stable complex, and it uses scoring functions to estimate the force of non-covalent interactions between a ligand and molecular target. This technique has been used widely to identify potential inhibitors of SARS-CoV-2 replication [16, 49]. The results of virtual screening of phytochemicals from Vernonia amygdalina and Occinum gratissimum against the 3chymotrypsin-like protease (3CL ${ }^{\text {pro }}$ ) of the novel SARS-CoV-2 alongside with the reference inhibitors (lopinavir and ritonavir) is represented in Table S1 (supplementary material). From the results, a hit list of 21 phytochemicals (Table S2) were selected based on their orientation at the catalytic site, the interacting residues and binding affinities comparable to those of reference inhibitors, lopinavir $(\Delta \mathrm{G}=-7.2 \mathrm{Kcal} / \mathrm{mol})$ and ritonavir $(\Delta \mathrm{G}=-7.2 \mathrm{Kcal} / \mathrm{mol})$.

Further binding docking of the topmost 10 compounds (Table 2) against the active regions of the target protein in SARSCoV and MERS-CoV (Table 1), revealed that, these chemical structures (Table 2) had considerable docking scores

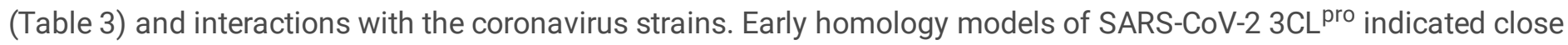
structural relation to those of other coronaviruses. Superimposition of the X-ray crystal structures of the $3 \mathrm{CL}^{\text {pro }}$ of SARSCoV-2, SARS-CoV and MERS-CoV indicates a considerable degree of structural similarity and conservation of the active 
site [8]. This is currently exploited for the development of SARS-CoV-2 3CL ${ }^{\text {pro }}$ inhibitors that were based on previous compounds targeting the $3 \mathrm{CL}^{\text {pro }}$ of SARS-CoV or MERS-CoV [8].

Table 2: Structures of reference inhibitors and top docked phytochemicals with the active sites of 3-Chymotrypsin-like proteases of Coronaviruses 


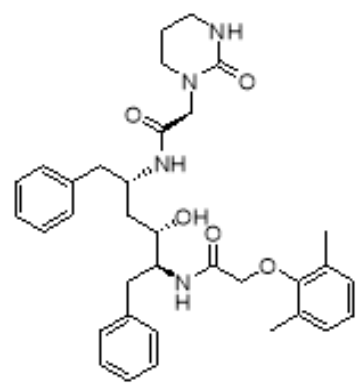

\section{S2 Ritonavir}

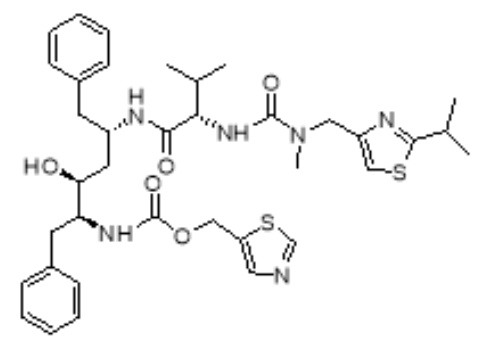
1 Vernolide
Sesquiterpene

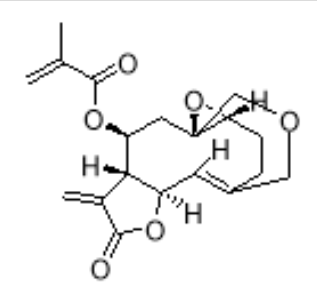
Vernonia amygdalina
lactones

$\begin{array}{ll}2 \text { Vernomygdin } & \text { Sesquiterpene } \\ \text { lactones }\end{array}$
Vernonia amygdalina

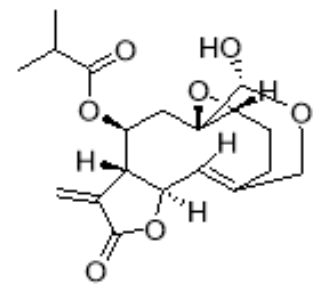

3 11,13-dihydrovernodalin Sesquiterpene

lactones

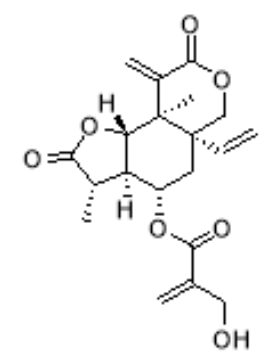

Vernonia amygdalina 

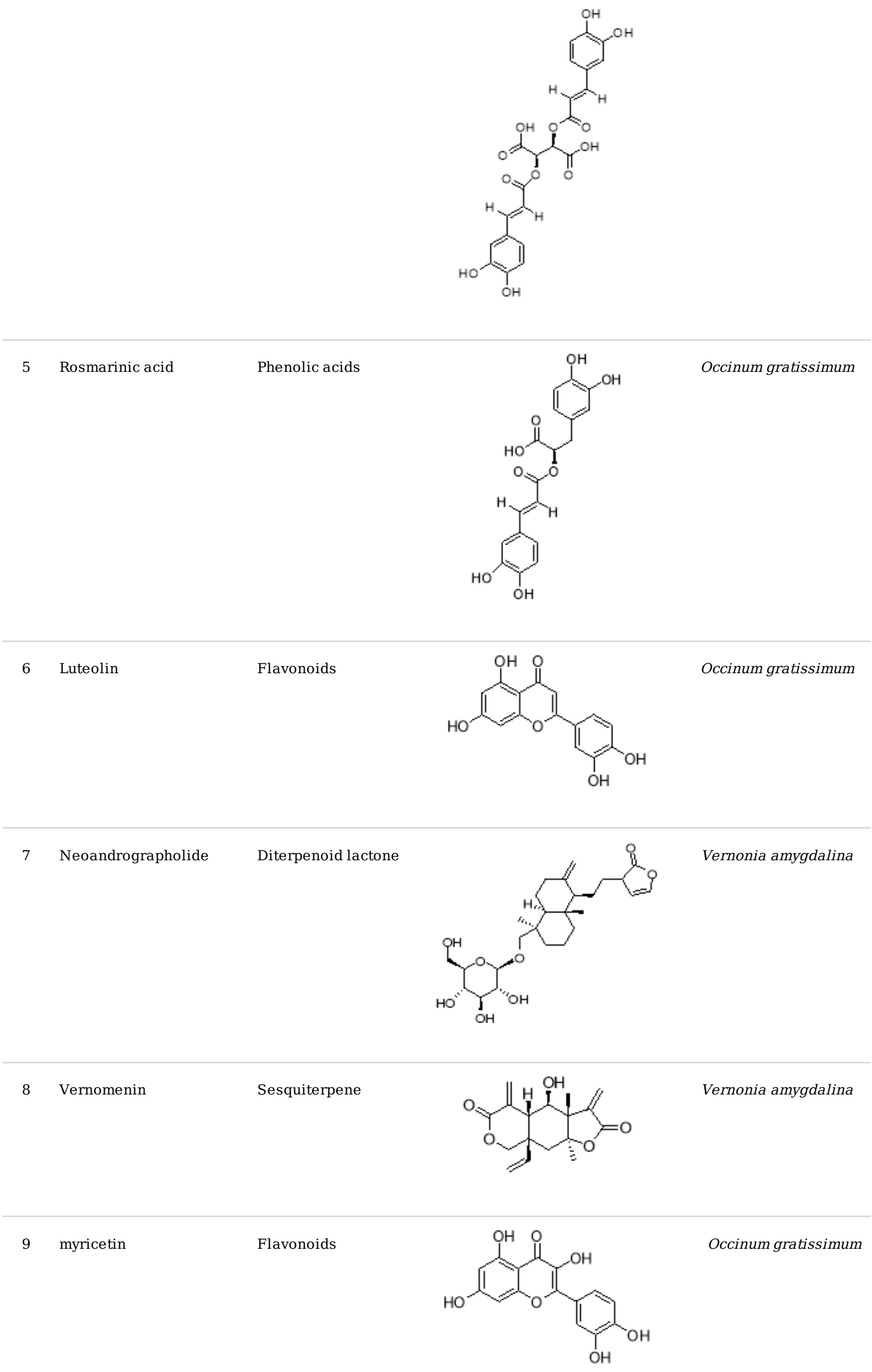
<smiles>COc1cc(-c2oc3cc(O)cc(O)c3c(=O)c2O)ccc1O</smiles>

Table 3

Binding energies of top ten ranked phytochemicals docked in the active sites of 3-Chymotrypsin-like proteases of coronaviruses.

\begin{tabular}{|lllll|}
\hline \multirow{2}{*}{ S/N } & Compounds & \multicolumn{3}{l|}{ Binding energies (Kcal/mol) } \\
\cline { 3 - 5 } & & SARS-CoV-2 & SARS-CoV & MERS-CoV \\
\hline S1 & Lopinavir & -7.2 & -8.3 & -7.5 \\
\hline S2 & Ritonavir & -7.2 & -7.2 & -7.1 \\
\hline 1 & Vernolide & -8.0 & -7.9 & -7.7 \\
\hline 2 & Vernomygdin & -7.9 & -7.7 & -7.2 \\
\hline 3 & 11, 13-dihydrovernodalin & -7.8 & -7.8 & -7.2 \\
\hline 4 & chicoric acid & -7.7 & -7.4 & -8.9 \\
\hline 5 & Rosmarinic acid & -7.7 & -7.2 & -8.7 \\
\hline 6 & Luteolin & -7.7 & -7.7 & -8.3 \\
\hline 7 & Neoandrographolide & -7.7 & -8.3 & -8.1 \\
\hline 8 & Vernomenin & -7.7 & -6.9 & -6.7 \\
\hline 9 & Myricetin & 7.7 & -7.5 & -8.0 \\
\hline 10 & Isorhamnetin & -7.6 & -8.0 & -8.4 \\
\hline
\end{tabular}

While the top three ranked phytochemicals SARS-CoV-2 3CLpro were found to be vernolide, vernomygdin and 11, 13dihydrovernodalin (-8.0, -7.9 and $-7.8 \mathrm{kcal} / \mathrm{mol}$ respectively); neoandrographolide, isorhamnetin and vernolide $(-8.3,-8.0$ and $-7.8 \mathrm{kcal} / \mathrm{mol}$ respectively) were topmost against SARS-CoV 3CL ${ }^{\text {pro; }}$ and chicoric acid, rosmarinic acid and isorhamnetin (-8.9, -8.7 and $-8.4 \mathrm{kcal} / \mathrm{mol}$ respectively) against MERS-CoV (Table 3). It was observed that the top three ranked phytochemicals for SARS-CoV-2 and SAR CoV 3CL ${ }^{\text {pros }}$ were isolated from Vernonia amygdalina while those for MERS-CoV $3 \mathrm{CL}^{\text {pro }}$ were from Occinum gratissimum.

\subsection{Molecular interactions between the top docking phytochemicals and the active sites of $3 \mathrm{CL}$ pro of coronaviruses}

A monomer of $3 \mathrm{CL}^{\text {pro }}$ is made up of three domains: domain I (residues 8-101), domain II (residues 102-184), and domain III (residues 201-303) and a long loop (residues 185-200) connects domains II and III. Domains I and II comprise six-stranded antiparallel $\beta$-barrels with the substrate binding site at the intersection of the two domains. The 
enzymatic activity of 3CLpro resides in the catalytic dyad of Cys ${ }^{145}$ and $\mathrm{His}^{41}$ [50]. The substrate-binding pocket lies in the cleft between domains I and II, and features the catalytic dyad residues Cys145 and His41. The substrate-binding pocket is divided into a series of subsites (including S1, S2, S4 and S1'), each accommodating a single but consecutive amino acid residue in the substrate. Ser1 in each one monomer interacts with Phe140 and Glu166 of the other monomer to stabilize the S1 subsite, a structural feature that is essential for catalysis [51]. The current study revealed that, the reference drugs and the top-docking phytocompounds are stabilized by numerous non-covalent interactions in the active regions of the target protein of the coronaviruses as shown in Table 4. 
Table 4

Interacting amino acid residues of the 3-Chymotrypsin-like proteases of Coronaviruses with the top phytochemicals of Vernonia amygdalina and Occinum gratissimum

\begin{tabular}{|c|c|c|c|c|}
\hline Compounds & Coronavirus & $\begin{array}{l}\text { Residues involved in hydrogen bonding } \\
\text { (bond distance, } \AA \text { ) }\end{array}$ & $\begin{array}{l}\text { Residues } \\
\text { involved in } \\
\text { hydrophobic } \\
\text { interactions }\end{array}$ & $\begin{array}{l}\text { Residues } \\
\text { involved in } \\
\text { others } \\
\text { interactions }\end{array}$ \\
\hline Lopinavir (S1) & SARS-Cov-2 & $\begin{array}{l}\mathrm{GLU}^{166}(2.97) \mathrm{ASN}^{142}(2.97) \mathrm{PRO}^{168} \\
(2.97) \mathrm{SER}^{144}(2.97)\end{array}$ & $\begin{array}{l}\mathrm{MET}^{49} \mathrm{HIS}^{41} \\
\mathrm{LEU}^{27}\end{array}$ & $\mathrm{CYS}^{145}$ \\
\hline Ritonavir (S2) & & $\operatorname{SER}^{46}(\mathbf{2 . 4 6}) \mathrm{THR}^{26}$ (3.24) & $\mathrm{MET}^{49} \mathrm{MET}^{165}$ & $\mathrm{GLU}^{166}$ \\
\hline Vernolide & & $\mathrm{GLY}^{143}$ (2.00) MET ${ }^{165}$ (3.63) $\mathrm{HIS}^{41}$ (2.25) & $\mathrm{CYS}^{145}$ & \\
\hline Vernomygdin & & $\begin{array}{l}\mathrm{GLU}^{166} \text { (2.97) } \mathrm{HIS}^{163} \text { (2.97) } \mathrm{ASN}^{142} \text { (2.97) } \\
\mathrm{GLY}^{143}(\mathbf{2 . 9 7}) \mathrm{MET}^{165}(\mathbf{2 . 9 7})\end{array}$ & $\begin{array}{l}\mathrm{CYS}^{145} \mathrm{LEU}^{27} \\
\mathrm{MET}^{4}\end{array}$ & \\
\hline $\begin{array}{l}\text { 11, } 13- \\
\text { dihydrovernodalin }\end{array}$ & & $\mathrm{CYS}^{145}$ (2.74) ASN ${ }^{142}$ (2.25) & $\begin{array}{l}\mathrm{MET}^{165} \mathrm{HIS}^{41} \\
\mathrm{LEU}^{27}\end{array}$ & \\
\hline Lopinavir (S1) & SARS-CoV & $\begin{array}{l}\mathrm{CYS}^{145}(\mathbf{2 . 4 9}) \mathrm{THR}^{25}(\mathbf{2 . 7 4}) \mathrm{GLU}^{166}(\mathbf{2 . 1 0}, \\
\mathbf{2 . 0 8})\end{array}$ & $\mathrm{MET}^{49}$ & $\mathrm{HIS}^{41}$ \\
\hline Ritonavir (S2) & & $\begin{array}{l}\operatorname{THR}^{24}(2.31) \mathrm{HR}^{25} \text { (2.47) } \mathrm{THR}^{26}(2.92) \\
\mathrm{ASN}^{142} \text { (3.12) }\end{array}$ & $\begin{array}{l}\mathrm{CYS}^{44} \mathrm{CYS}^{145} \\
\mathrm{MET}^{49}\end{array}$ & \\
\hline Neoandrographolide & & $\begin{array}{l}\operatorname{ASP}^{48}(2.92) \operatorname{GLU}^{166}(3.13,3.37) \mathrm{GLU}^{47} \\
(2.47)\end{array}$ & $\begin{array}{l}\mathrm{HIS}^{41} \mathrm{CYS}^{145} \\
\mathrm{CYS}^{44} \mathrm{MET}^{165} \\
\mathrm{MET}^{49}\end{array}$ & $\mathrm{HIS}^{163}$ \\
\hline Isorhamnetin & & 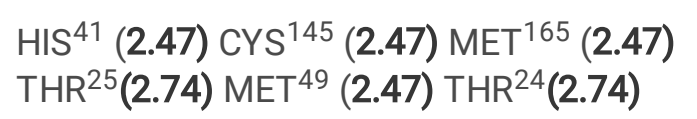 & $\mathrm{MET}^{49}$ & $\mathrm{GLU}^{47}$ \\
\hline Vernolide & & $\operatorname{ALA}^{46}(\mathbf{2 . 4 7}) \mathrm{THR}^{26}(\mathbf{2 . 7 4}) \mathrm{GLY}^{26}$ (2.74) & $\mathrm{HIS}^{41} \mathrm{CYS}^{145}$ & \\
\hline Lopinavir & MERS-CoV & $\operatorname{GLN}^{169}(2.81) \mathrm{GLY}^{167}(2.66)$ & $\begin{array}{l}\text { HIS }^{41} \text { CYS }^{145} \\
\text { CYS }^{44} \text { MET }^{25} \\
\text { LEU }^{49} \text { ALA }^{46}\end{array}$ & \\
\hline Ritonavir & & $\begin{array}{l}\mathrm{CYS}^{145}(\mathbf{3 . 3 1}) \mathrm{CYS}^{148}(\mathbf{3 . 6 7}, \mathbf{2 . 7 5}) \mathrm{GLY} \\
(\mathbf{2} . \mathbf{9 2}, \mathbf{3 . 0 3}) \mathrm{GLY} \\
\end{array}$ & $\begin{array}{l}\text { LEU }^{49} \mathrm{ALA}^{46} \\
\mathrm{GLN}^{169}\end{array}$ & $\mathrm{HIS}^{41}$ \\
\hline chicoric acid & & $\begin{array}{l}\mathrm{CYS}^{145}(\mathbf{3 . 6 8}) \mathrm{GLY}^{146}(\mathbf{2 . 3 6}) \mathrm{HIS}^{166}(2.90 \\
\text { 1.98) SER } \\
\text { (1.92) } \mathrm{LYS}^{191}(\mathbf{2 . 4 8}) \mathrm{LEU}^{144}(\mathbf{1 . 9 9}) \mathrm{GLU}^{169}(\mathbf{2} .70) \mathrm{THR}^{193}\end{array}$ & $\operatorname{LEU}^{49}$ & \\
\hline Rosmarinic acid & & $\begin{array}{l}\mathrm{HIS}^{41} \text { (3.04) LEU }{ }^{49} \text { (2.92) TRY54 (2.68) } \\
\mathrm{THR}^{193} \text { (2.72) }\end{array}$ & $\mathrm{GLY}^{192} \mathrm{MET}^{168}$ & \\
\hline Isorhamnetin & & $\operatorname{GLU}^{169}(2.70) \mathrm{HIS}^{41}$ (3.06) LEU ${ }^{144}$ (2.70) & $\mathrm{MET}^{168} \mathrm{CYS}^{145}$ & \\
\hline
\end{tabular}

Lopinavir and ritonavir, the antiretroviral protease inhibitors which were originally developed for use against HIV and later recommended for the treatment of SARS and MERS [52], were used as reference drugs. The interactions of lopinavir were majorly through hydrogen bonds and hydrophobic interactions, with few electrostatic interactions. The 4-hydroxyl and 
acetyl group of lopinavir interacted via hydrogen bond to $\mathrm{GLU}^{166}$ and SER ${ }^{144}$ of the domain I and II of $3 \mathrm{CL}^{\text {pro }}$ of SARSCoV-2 while the 3-methyl and 1-phenyl moiety interacted via a carbon hydrogen interaction. The 1-phenyl and the methyl moieties of the 2,6-dimethylphenoxy interacted via hydrophobic interactions with the catalytic dyad (Cys ${ }^{145}$ and His $^{41}$ ) residues of $3 \mathrm{CL}^{\text {pro }}$ of SARS-CoV-2 (Fig. 1). For 3CL ${ }^{\text {pro }}$ of SARS-CoV, the 1-amino group of 2-oxo-1,3-diazinan-1-yl, 4hydroxyl and acetyl groups of lopinavir interacted via $\mathrm{H}$-bond with $\mathrm{GLU}^{166}, \mathrm{THR}^{25}$ and $\mathrm{CYS}^{145}$ in the same domain as SARS-CoV-2 while the 3-methyl and 1-phenyl groups formed an alkyl and pi-sulfur interaction with MET ${ }^{49}$ and CYS $^{145}$ respectively (Figure S1). In the case of MERS-CoV, two hydrogen bonds were observed between GLU ${ }^{169}$ and GLN ${ }^{167}$ and the carbonyl group and amino group of the butanamide moiety of lopinavir respectively (Figure S2), while hydrophobic interactions were formed by the phenyl rings. In the same vein, ritonavir having the same binding affinities as lopinavir interacted in a different manner with $3 \mathrm{CL}^{\text {pro }}$ of the coronaviruses.

The 15-hydroxy, 7-oxatetracyclo moiety and the carbonyl group of methylprop-2-enoate of vernolide interacted via $\mathrm{H}$-bond with $\mathrm{HIS}^{41}$, GLY ${ }^{143}$ and MET ${ }^{165}$ of $3 \mathrm{CL}^{\text {pro }}$ of SARS-CoV-2, while the heptadec-9-en-3-yl ring formed an alkyl interaction with $\mathrm{CYS}^{145}$ (Table 4). The hydrogen bonds observed between vernomygdin and $\mathrm{HIS}^{163}$, GLU ${ }^{166}$, and $\mathrm{GLY}^{143}$ of $3 \mathrm{CL}^{\text {pro }}$ of SARS-CoV-2 were contributed by dihydrofuran-2 $(3 \mathrm{H})$-one and the carbonyl group of methylpropanoate. The heptadec-9en-3-yl ring and the alkyl group of methylpropanoate moiety were responsible for the alkyl interactions with which amino acids and $3 \mathrm{CL}^{\text {pro }}$ of SARS-CoV-2. The hydroxyl group of hydroxymethyl-prop-2-enoate of 11, 13-dihydrovernodalin contributed the only hydrogen bonds with $\mathrm{CYS}^{145}$ of $3 \mathrm{CL}^{\text {pro }}$ of SARS-CoV-2. Several alkyl and pi-alkyl interactions were formed by the rings and methyl group of the furan ring of 11, 13-dihydrovernodalin and 3CL ${ }^{\text {pro }}$ of SARS-CoV-2. Vernolide, vernomygdin and 11,13-dihydrovernodalin, the best docked phytochemicals in the SARS-CoV-2 3CL ${ }^{\text {pro }}$ were observed to interact with the $\mathrm{S} 1$ subsite residues such as $\mathrm{HIS}^{41}, \mathrm{ASN}^{142}, \mathrm{GLY}^{143}, \mathrm{SER}^{144}$ and the $\mathrm{GLU}^{166}$ residue of $\beta 11$. Interactions with the $S 1$ and $\beta 11$ residues have been reported for some other inhibitors of SARS-CoV-2 replication [6, 51], suggesting that these three phytochemicals may effectively inhibit the proliferation of the virus. Interactions of the compounds at the $\mathrm{S} 2$ subsite were predominantly hydrophobic except for vernomygdin that formed a hydrogen bond with $\mathrm{HIS}^{163}$ and important residue in the hydrophobic pack that have been implicated in its catalytic activity [6] (Table 4). The binding of the top three ranked compounds docked in $3 \mathrm{CL}^{\text {pro }}$ of the coronaviruses revealed that all the phytochemicals of $V$. amygdalina and isorhamnetin interacted with both amino acids of the catalytic dyad, indicating that they may be more effective inhibitors of the enzyme. The stability of the complexes formed stemmed from the vast number of interactions with some important active site residues $\mathrm{HIS}^{41}, \mathrm{MET}^{49}, \mathrm{MET}^{165}, \mathrm{THR}^{25}$, LEU ${ }^{27}, \mathrm{ASP}^{48}$, LEU ${ }^{50}, \mathrm{LEU}^{141}, \mathrm{CYS}^{145}, \mathrm{HIS}^{164}$, $\mathrm{LEU}^{167}, \mathrm{PRO}^{168}, \mathrm{AEP}^{187}$, and $\mathrm{ALA}^{191}$ which have been reported to be significant for the binding of the inhibitors with $3 C L^{\text {pro }}[53]$.

SARS-CoV $3 \mathrm{CL}^{\text {pro }}$ had the highest binding affinity for neoandrographolide, a diterpene lactone obtained from $V$. amygdalina. The $2 \mathrm{H}$-Furan-5-one ring formed two hydrogen bonds to ASP ${ }^{48}$ and GLU ${ }^{47}$. An alkyl interaction was formed by the methyl group at the oxan-2-yl-oxymethyl junction with CYS ${ }^{145}$ while the several pi-alkyl interactions were majorly formed by the $1 \mathrm{H}$-naphthalen-1-yl and $2 \mathrm{H}$-Furan-5-one ring (Figure S1). Isorhamnetin, an 0-methylated flavon-ol obtained from Vernonia amygdalina interacted via conventional H-bonds with $\mathrm{GLU}^{166}, \mathrm{GLY}^{143}$ and $\mathrm{THR}^{45}$. A carbon hydrogen interaction was observed with $\mathrm{CYS}^{145}$ and $\mathrm{THR}^{24}$, while pi-cation, pi-sulfur and pi-alky were observed between the rings and $\mathrm{HIS}^{45}, \mathrm{MET}^{49}$ and $\mathrm{CYS}^{145}$ respectively. The carbonyl group of methylprop-2-enoate moiety and 15-hydroxyl group of vernolide formed a conventional hydrogen bond with GLY ${ }^{143}$ and $\mathrm{THR}^{25}$ of SARS-CoV 3CL ${ }^{\text {pro }}$. Pi-alkyl and alkyl interactions of the heptadec-9-en-3-yl with $\mathrm{HIS}^{41}$ and $\mathrm{CYS}{ }^{145}$ were also observed.

Chicoric acid, a constituent of Occinum gratissimum, was the best docked phytochemical to MERS-CoV $3 \mathrm{CL}^{\text {pro }}$. The hydroxyl and carbonyl groups on prop-2-enoyl[oxy]butanedioic moiety of chicoric acid interacted via several $\mathrm{H}$-bonds with the residues at the active site. The hydroxyl and carbonyl groups on prop-2-enoyl[oxy]propanoic moiety of

Page $12 / 29$ 
rosmarinic acid contributed the 3 hydrogen bonds to TYR ${ }^{54}$, LEU 49 and HIS ${ }^{41}$ (Figure S2), while the first 3,4dihydroxyphenyl moiety formed the hydrophobic interactions. $\mathrm{HIS}^{41}$ formed both hydrogen bond and pi-pi T-shaped interaction with the carbonyl group on the chromen-4-one moiety of isorhamnetin. The 4-hydroxy-3-methoxyphenyl moiety of isorhamnetin formed carbon hydrogen and pi-alkyl interactions with CYS ${ }^{145}$ (Figure S2).

\subsection{Optimization of docking interactions of phytocompounds with SARS-CoV-2 3CL ${ }^{\text {Pro }}$ conformations}

An in-depth docking simulation of the phytocompounds was performed to validate their docking and interactions with the target protein. Figure 2 shows the average binding affinities of the best ten phytocompounds along with the reference inhibitors (positive controls) against the five different representative conformations gotten from the clustering analysis of the SARS-CoV-2 3CL ${ }^{\text {pro }}$ MDS trajectories (see Figure S3). The means and the standard errors of the mean of the 5 binding energies for each representative conformation of SARS-CoV-2 $3 \mathrm{CL}^{\text {pro }}$ were calculated for each phytochemicals and reference inhibitors. As reflected from the binding energy values, the ten phytochemicals are able to bind effectively to the SARS-CoV-2 $3 \mathrm{CL}^{\text {pro }}$ different conformations, just like the positive controls. The binding energy values ranged from - 6.1 Kal/mol (rosmarinic acid) down to $-8.1 \mathrm{Kcal} / \mathrm{mol}$ (neoandrographolide and chicoric acid). As reflected from Fig. 2, vernolide, neoandrographolide, myricetin, chicoric acid, luteolin, and Isorhamnetin (green columns) are the compounds with best the binding affinities to SARS-CoV-2 $3 \mathrm{CL}^{\text {pro }}$. To further analyze the data, we examined the docking complexes of these best compounds using the PLIP analysis web server. We examined the docking complexes of these best compounds using the PLIP analysis webserver to further analyze the data.

From the docking results, five complexes for each phytochemical were generated. The best representative complex for each phytochemical was selected based on the binding affinity for further analysis using the PLIP webserver. The details of the interactions established upon docking of the reference inhibitors and the best ten phytochemicals against SARSCoV-2 3CL ${ }^{\text {pro }}$ are presented in Table 5. The most reported types of interactions are hydrogen bonding and few hydrophobic contacts in some complexes. At least three hydrogen bond, and up to seven were reported in the docking complexes between the compounds and SARS-CoV-2 3CL ${ }^{\text {pro }}$. The most-reported residues from the $3 \mathrm{CL}^{\text {pro }}$ that interacted with the ligands (represented in bold in Table 5) are ASN ${ }^{142}, \mathrm{GLY}^{143}, \mathrm{SER}^{144}, \mathrm{CYS}^{145}$, and GLU ${ }^{166}$, and these formed 6, 9, 14,7 , and 5 interactions with the ligands, respectively. $C Y S^{145}$ is one of the $3 \mathrm{CL}^{\text {pro }}$ active site dyads (HIS ${ }^{41}$ and $\left.C Y S^{145}\right)$, and it was reported in all the ligands except myricetin and luteolin. 
Table 5

The interactions of the top 10 ranked phytochemicals of Vernonia amygdalina and Occinum gratissimum and positive control (Ritonavir and Lopinavir) for the best representative conformation from the cluster analysis of SARS-CoV-2 $3 \mathrm{CL}^{\text {pro }}$ molecular dynamics simulation (MDS) trajectories

\begin{tabular}{|c|c|c|c|c|c|}
\hline \multirow[t]{2}{*}{ Compound } & \multirow{2}{*}{$\begin{array}{l}\begin{array}{l}\text { Binding } \\
\text { energies }\end{array} \\
\text { (kcal/mol) }\end{array}$} & \multicolumn{2}{|c|}{ H-bonding } & \multicolumn{2}{|c|}{ Hydrophobic interactions } \\
\hline & & Number & Residues from SARS-CoV-2 Mpro & Number & $\begin{array}{l}\text { Residues from } \\
\text { SARS-CoV-2 } \\
M^{\text {pro }}\end{array}$ \\
\hline Ritonavir & -6.4 & 6 & $\begin{array}{l}\operatorname{ASN}^{142}(2), G L Y^{143}, \text { SER }^{144}, \text { CYS }^{145} \\
\text { and GLU } \\
166\end{array}$ & 1 & $\mathrm{MET}^{165}$ \\
\hline Lopinavir & -6.3 & 5 & $\begin{array}{l}\operatorname{ASN}^{142}, \operatorname{GLY}^{143}, \operatorname{ASP}^{178}(2), \text { and } \\
\operatorname{GLN}^{189}\end{array}$ & 1 & $\mathrm{THR}^{25}$ \\
\hline Vernolide & -7.5 & 3 & $\mathrm{GLY}^{143}, \mathrm{SER}^{144}$, and $\mathrm{CYS}^{145}$ & 1 & $\mathrm{MET}^{165}$ \\
\hline Vernomygdin & -6.9 & 5 & $\begin{array}{l}\text { ASN }^{142}, \text { GLY }^{143}, \text { SER }^{144}, \text { CYS }^{145} \text {, and } \\
\text { GLN }^{189}\end{array}$ & 2 & $\begin{array}{l}\text { MET }^{165}, \text { and } \\
\text { GLU }^{166}\end{array}$ \\
\hline $\begin{array}{l}\text { 11, } 13- \\
\text { dihydrovernodalin }\end{array}$ & -6.6 & 6 & $\begin{array}{l}\operatorname{ASN}^{28}(2), \mathrm{GLY}^{143}, \mathrm{SER}^{144}, \mathrm{CYS}^{145}, \\
\text { and GLU } \\
166\end{array}$ & 3 & $\begin{array}{l}\operatorname{LEU}^{27}(2), \text { and } \\
\mathrm{MET}^{165}\end{array}$ \\
\hline Neoandrographolide & -7.7 & 7 & $\begin{array}{l}\text { THR }^{45}, \text { SER }^{46}, \text { LEU }^{50}, \text { ASN }^{142} \text {, } \\
\text { GLY }^{143}, \text { SER }^{144} \text {, and } \text { CYS }^{145}\end{array}$ & 1 & $\mathrm{THR}^{25}$ \\
\hline Vernomenin & -6.4 & 3 & GLY $^{143}$, SER $^{144}$, and $\mathrm{CYS}^{145}$ & 2 & $\begin{array}{l}\mathrm{THR}^{25} \text {, and } \\
\mathrm{LEU}^{27}\end{array}$ \\
\hline Myricetin & -7.1 & 7 & $\begin{array}{l}\mathrm{LEU}^{141}, \mathrm{ASN}^{142}, \mathrm{GLY}^{143}, \mathrm{SER}^{144}(3) \text {, } \\
\text { and } \mathrm{GLU}^{166}\end{array}$ & 0 & \\
\hline Chicoric acid & -7.3 & 6 & $\begin{array}{l}\text { LEU }^{141}, \text { ASN }^{142}, \text { GLY }^{143}, \text { SER }^{144}(2), \\
\text { and } \text { CYS }^{145}\end{array}$ & 1 & GLN $^{189}$ \\
\hline Luteolin & -7.2 & 4 & $\operatorname{SER}^{144}, \operatorname{GLU}^{166}(2)$, and GLN ${ }^{189}$ & 0 & \\
\hline Rosmarinic acid & -6.8 & 7 & $\begin{array}{l}\operatorname{THR}^{26}(2), \mathrm{PHE}^{140}, \mathrm{LEU}^{141}, \mathrm{GLY}^{143}, \\
\mathrm{SER}^{144} \text {, and } \mathrm{CYS}^{145}\end{array}$ & 0 & \\
\hline Isorhamnetin & -7.4 & 6 & $\begin{array}{l}\text { ASN }^{142}, \text { GLY }^{143}, \text { SER }^{144}(3), \text { and } \\
\text { CYS }^{145}\end{array}$ & 0 & \\
\hline
\end{tabular}

So far, two terpenoid structures viz: vernolide and neoandrographolide with strong interactions with the active region of SARS-CoV-2 $3 \mathrm{CL}^{\text {pro }}$ have been identified (Fig. 2, Table 5 and Fig. 3). The surface views of these structures in the substrate binding pocket of SARS-CoV-2 3CL ${ }^{\text {Pro }}$ are shown in Fig. 4.

Binding interactions of neoandrographolide at the enzyme catalytic site is stabilized by several $\mathrm{H}$ bonds between its $2 \mathrm{H}$ Furan-5-one ring and key residues (ASN142, GLY143, SER144, CYS145) of catalytic pocket of the enzyme, which led this ring to be sandwiched between CYS145 and ASN142 (Fig. 3). Furthermore, neoandrographolide structure inserts into the bulky hydrophobic S1/S2 subsites (composed of the side chains of HIS41, MET49, HIS41, ASN142, GLY143, SER144, 
and MET165) (Fig. 3 and Fig. 4b). Consequently, neoandrographolide was accommodated in the substrate-binding pocket and interacted with the catalytic residues, the oxyanion loop (residues 138-145), and the S1/S2 subsites, which are the key elements for the recognition of substrates. Interactions with the $\mathrm{S} 1$ have been reported for some other inhibitors of SARS-CoV-2 replication $[6,51]$ suggesting that this structure may effectively inhibit the proliferation of the virus. With the aid of an array of direct and indirect hydrogen bonds with ASN142/GLY143/SER144/CYS145, neoandrographolide may fix the conformation of the flexible oxyanion loop, which served to stabilize the tetrahedral transition state of the proteolytic reaction. This binding mode of neoandrographolide is similar in many respect to that of baicalein, the first natural noncovalent, nonpeptidomimetic inhibitor of SARS-CoV-2 3CLpro derived from Shuanghuanglian [54]. Vernolide, another terpenoid structure (sesquiterpene lactone) isolated from Vernonia amygdalina is another potential non-covalent inhibitor of SARS-CoV-2 $3 \mathrm{CL}^{\text {Pro }}$ inhibitor. Its interactions with the active site of this enzyme mimic the non-covalent interactions of carmofur, a potent covalent inhibitor of this enzyme which also establishes non-covalent interactions with its target [55]. The carbonyl group of methylprop-2-enoate moiety of vernolide occupies the oxyanion hole and forms hydrogen bonds with the backbone amides of Gly143, and Cys145 (Fig. 3 and Fig. 4a), mimicking the tetrahedral oxyanion intermediate formed during protease cleavage. A side chain of vernolide inserts into the bulky hydrophobic S2 subsite (composed of the side chains of HIS41 and MET165) (Fig. 3 and Fig. 4a). Therefore, these terpenoid structures alongside other phytocompounds from the source plants may be suggested as inhibitors of SARS-CoV-2 3CL ${ }^{\text {pro. }}$.

\subsection{In Silico Drug-likeness and Pharmacokinetic properties of vernolide, Neoandrographolide, and other topmost phytocompounds}

The top 6 phytocompounds (Neoandrographolide, Vernolide, Isorhamnetin, Chicoric acid, Luteolin, and Myricetin) from the docking analysis to the representative conformation gotten from the clustered MDS trajectories were subjected to the

predictive drug-likeness and ADMET (Absorption, Distribution, Metabolism, Excretion, and Toxicity) filtering analyses. The result of the analyses for the six-top phytocompounds is represented in the Table 6. ability to pass the high human intestinal absorption, low acute oral toxicity with a good bioavailability score (Table 5). 
Table 6

In silico Physicochemical and $\mathrm{ADMET}^{\mathrm{a}}$ parameters of the top-binding phytochemicals of Vernonia amygdalina and Occinum gratissimum with 3-Chymotrypsin-like protease of SARS-CoV-2

\begin{tabular}{|c|c|c|c|c|c|c|}
\hline $\begin{array}{l}\text { a) } \\
\text { Physicochemical } \\
\text { properties }\end{array}$ & Vernolide & Neoandrographolide & Isorhamnetin & Chicoric acid & Luteolin & Myricetin \\
\hline $\begin{array}{l}\text { Molecular } \\
\text { weight }(\mathrm{g} / \mathrm{mol})\end{array}$ & 362.37 & 480.59 & 316.26 & 474.37 & 286.23 & 318.24 \\
\hline $\begin{array}{l}\text { Num. heavy } \\
\text { atoms }\end{array}$ & 26 & 34 & 23 & 34 & 21 & 23 \\
\hline $\begin{array}{l}\text { Num. arom. } \\
\text { Heavy atoms }\end{array}$ & 0 & 0 & 16 & 12 & 16 & 16 \\
\hline $\begin{array}{l}\text { Num. rotatable } \\
\text { bonds }\end{array}$ & 3 & 7 & 2 & 11 & 1 & 1 \\
\hline $\begin{array}{l}\text { Num. H-bond } \\
\text { acceptors }\end{array}$ & 7 & 8 & 7 & 12 & 6 & 8 \\
\hline $\begin{array}{l}\text { Hydrogen bond } \\
\text { donor }\end{array}$ & 1 & 4 & 4 & 6 & 4 & 6 \\
\hline cLogP & 0.93 & 2.63 & 1.87 & 2.01 & 2.52 & 1.18 \\
\hline $\begin{array}{l}\text { Molar } \\
\text { Refractivity }\end{array}$ & 89.51 & 125.27 & 82.50 & 114.00 & 76.01 & 80.06 \\
\hline TPSA $\left(\AA^{2}\right)$ & 94.59 & 125.68 & 120.36 & 208.12 & 111.13 & 151.59 \\
\hline \multicolumn{7}{|c|}{ Drug-likeness } \\
\hline Lipinski & Yes & Yes & Yes & No & Yes & Yes \\
\hline Veber & Yes & Yes & Yes & Yes & Yes & Yes \\
\hline Ghose & Yes & No & Yes & No & Yes & No \\
\hline Egan & Yes & Yes & Yes & No & Yes & No \\
\hline Muegge & Yes & Yes & Yes & No & Yes & No \\
\hline $\begin{array}{l}\text { Bioavailability } \\
\text { Score }\end{array}$ & 0.55 & 0.55 & 0.55 & 0.11 & 0.55 & 0.55 \\
\hline \multicolumn{7}{|c|}{ Absorption (Probability) } \\
\hline \multicolumn{7}{|l|}{ (b) Admet SAR } \\
\hline HIA & $\begin{array}{l}\mathrm{HIA+} \\
(0.58)\end{array}$ & HIA- (0.127) & HIA- (0.498) & $\mathrm{HIA}+(0.883)$ & $\begin{array}{l}\text { HIA+ } \\
(0.9650)\end{array}$ & $\begin{array}{l}\text { HIA- } \\
(0.437)\end{array}$ \\
\hline $\begin{array}{l}\text { Caco-2 } \\
\text { Permeability } \\
\mathrm{Cm} / \mathrm{s}\end{array}$ & $\begin{array}{l}\text { Caco2+ } \\
(-5.096)\end{array}$ & Caco2+ $(-5.84)$ & $\begin{array}{l}\text { Caco2+ } \\
(-5.217)\end{array}$ & Caco2+ (-6.709) & $\begin{array}{l}\text { Caco2+ } \\
(-5.12)\end{array}$ & $\begin{array}{l}\text { Caco2+ } \\
(-6.63)\end{array}$ \\
\hline $\begin{array}{l}\text { P-glycoprotein } \\
\text { Substrate }\end{array}$ & $\begin{array}{l}\text { Neg. } \\
(0.484)\end{array}$ & Pos. (0.778) & Neg. (0.015) & Neg. (0.051) & $\begin{array}{l}\text { Neg. } \\
(0.038)\end{array}$ & $\begin{array}{l}\text { Neg. } \\
(0.208)\end{array}$ \\
\hline
\end{tabular}

${ }^{a}$ ADMET: Absorption, distribution, metabolism, elimination, and toxicity; GI: Gastro-intestinal; BBB: Blood Brain Barrier; P-gp: permeability glycoprotein; CYP: cytochrome P450; hERG: human Ether-à-go-go-Related Gene; HIA : Human Intestinal Absorption; H-HT: Human Hepatotoxicity AMES: Ames Mutagenicity; DILl: Drug Induced Liver Injury; VD: Volume Distribution; PPB: Plasma Protein Binding 


\begin{tabular}{|c|c|c|c|c|c|c|}
\hline $\begin{array}{l}\text { a) } \\
\text { Physicochemical } \\
\text { properties }\end{array}$ & Vernolide & Neoandrographolide & Isorhamnetin & Chicoric acid & Luteolin & Myricetin \\
\hline $\begin{array}{l}\text { P-glycoprotein } \\
\text { Inhibitor }\end{array}$ & $\begin{array}{l}\text { Neg. } \\
(0.027)\end{array}$ & Neg. (0.007) & Pos. (0.538) & Neg. (0.193) & $\begin{array}{l}\text { Neg. } \\
(0.366)\end{array}$ & $\begin{array}{l}\text { Neg. } \\
(0.064)\end{array}$ \\
\hline \multicolumn{7}{|c|}{ Distribution (Probability) } \\
\hline $\begin{array}{l}\text { Blood-Brain } \\
\text { Barrier }\end{array}$ & $\begin{array}{l}\text { BBB }+ \\
(0.4 .39)\end{array}$ & BBB- $(0.476)$ & BBB- $(0.34)$ & $\mathrm{BBB}+(0.552)$ & $\begin{array}{l}\text { BBB- } \\
(0.464)\end{array}$ & $\begin{array}{l}\text { BBB- } \\
(0.4 .27)\end{array}$ \\
\hline PPB \% & 65.501 & 72.039 & 90.707 & 76.782 & 91.796 & 76.595 \\
\hline VD L/kg & -0.147 & -0.452 & -0.932 & -1.406 & -1.406 & -1.39 \\
\hline \multicolumn{7}{|c|}{ Metabolism (Probability) } \\
\hline $\begin{array}{l}\text { CYP450 1A2 } \\
\text { Inhibitor }\end{array}$ & $\begin{array}{l}\text { Neg. } \\
(0.069)\end{array}$ & Neg. (0.028) & Pos. (0.941) & Neg. (0.239) & $\begin{array}{l}\text { Neg. } \\
(0.069)\end{array}$ & $\begin{array}{l}\text { Neg. } \\
(0.133)\end{array}$ \\
\hline $\begin{array}{l}\text { CYP450 1A2 } \\
\text { Substrate }\end{array}$ & $\begin{array}{l}\text { Neg. } \\
(0.33)\end{array}$ & Neg. (0.258) & Neg. (0.456) & Neg. (0.262) & $\begin{array}{l}\text { Pos. } \\
(0.968)\end{array}$ & $\begin{array}{l}\text { Pos. } \\
(0.968)\end{array}$ \\
\hline $\begin{array}{l}\text { CYP450 3A4 } \\
\text { Inhibitor }\end{array}$ & $\begin{array}{l}\text { Neg. } \\
(0.149)\end{array}$ & Neg. (0.262) & Pos. (0.768) & Neg. (0.087) & $\begin{array}{l}\text { Neg. } \\
(0.412)\end{array}$ & $\begin{array}{l}\text { Neg. } \\
(0.376)\end{array}$ \\
\hline $\begin{array}{l}\text { CYP450 3A4 } \\
\text { Substrate }\end{array}$ & $\begin{array}{l}\text { Neg. } \\
(0.562)\end{array}$ & Neg. (0.523) & Neg. (0.428) & Neg. (0.15) & $\begin{array}{l}\text { Pos. } \\
(0.867)\end{array}$ & $\begin{array}{l}\text { Neg. } \\
(0.459)\end{array}$ \\
\hline $\begin{array}{l}\text { CYP4502C9 } \\
\text { Inhibitor }\end{array}$ & $\begin{array}{l}\text { Neg. } \\
(0.116)\end{array}$ & Neg. (0.144) & Neg. (0.183) & Neg. (0.071) & $\begin{array}{l}\text { Neg. } \\
(0.328)\end{array}$ & $\begin{array}{l}\text { Pos. } \\
(0.656)\end{array}$ \\
\hline $\begin{array}{l}\text { CYP450 2C9 } \\
\text { Substrate }\end{array}$ & $\begin{array}{l}\text { Neg. } \\
(0.313)\end{array}$ & Neg. (0.408) & Pos. (0.772) & Pos. (0.504) & $\begin{array}{l}\text { Neg. } \\
(0.0496)\end{array}$ & $\begin{array}{l}\text { Pos. } \\
(0.557)\end{array}$ \\
\hline $\begin{array}{l}\text { CYP4502C19 } \\
\text { Inhibitor }\end{array}$ & $\begin{array}{l}\text { Neg. } \\
(0.093)\end{array}$ & Neg. (0.103) & Neg. (0.24) & Neg. (0.157) & $\begin{array}{l}\text { Neg. } \\
(0.124)\end{array}$ & $\begin{array}{l}\text { Neg. } \\
(0.068)\end{array}$ \\
\hline $\begin{array}{l}\text { CYP450 2C19 } \\
\text { Substrate }\end{array}$ & $\begin{array}{l}\text { Neg. } \\
(0.474)\end{array}$ & Neg. (0.462) & Pos. (0.54) & Neg. (0.334) & $\begin{array}{l}\text { Pos. } \\
(0.542)\end{array}$ & $\begin{array}{l}\text { Neg. } \\
(0.345)\end{array}$ \\
\hline $\begin{array}{l}\text { CYP4502D6 } \\
\text { Inhibitor }\end{array}$ & $\begin{array}{l}\text { Neg. } \\
(0.296)\end{array}$ & Neg. (0.329) & Neg. (0.468) & Neg. (0.248) & $\begin{array}{l}\text { Neg. } \\
(0.463)\end{array}$ & $\begin{array}{l}\text { Neg. } \\
(0.318)\end{array}$ \\
\hline $\begin{array}{l}\text { CYP450 2D6 } \\
\text { Substrate }\end{array}$ & $\begin{array}{l}\text { Neg. } \\
(0.267)\end{array}$ & Neg. (0.274) & Neg. (0.41) & Neg. (0.415) & $\begin{array}{l}\text { Neg. } \\
(0.401)\end{array}$ & $\begin{array}{l}\text { Neg. } \\
(0.18)\end{array}$ \\
\hline \multicolumn{7}{|c|}{ Elimination } \\
\hline $\begin{array}{l}T_{1 / 2} \text { (Half Life } \\
\text { Time) }\end{array}$ & $0.883 \mathrm{~h}$ & $1.53 \mathrm{~h}$ & $0.658 \mathrm{~h}$ & $1.79 \mathrm{~h}$ & $0.745 \mathrm{~h}$ & $1.915 \mathrm{~h}$ \\
\hline $\begin{array}{l}\text { CL (Clearance } \\
\text { Rate) } \\
\mathrm{mL} / \mathrm{min} / \mathrm{kg}\end{array}$ & 1.914 & 1.032 & 1.951 & 0.823 & 1.919 & 1.709 \\
\hline & Toxicity & & & & & \\
\hline
\end{tabular}

${ }^{a}$ ADMET: Absorption, distribution, metabolism, elimination, and toxicity; GI: Gastro-intestinal; BBB: Blood Brain Barrier; P-gp: permeability glycoprotein; CYP: cytochrome P450; hERG: human Ether-à-go-go-Related Gene; HIA : Human Intestinal Absorption; H-HT: Human Hepatotoxicity AMES: Ames Mutagenicity; DILl: Drug Induced Liver Injury; VD: Volume Distribution; PPB: Plasma Protein Binding 


\begin{tabular}{|c|c|c|c|c|c|c|}
\hline $\begin{array}{l}\text { a) } \\
\text { Physicochemical } \\
\text { properties }\end{array}$ & Vernolide & Neoandrographolide & Isorhamnetin & Chicoric acid & Luteolin & Myricetin \\
\hline hERG Blockers & $\begin{array}{l}\mathrm{Ng} . \\
(0.256)\end{array}$ & Neg. $(0.474)$ & Neg. $(0.301)$ & Neg. $(0.578)$ & $\begin{array}{l}\text { Neg. } \\
(0.436\end{array}$ & $\begin{array}{l}\text { Neg. } \\
(0.353)\end{array}$ \\
\hline $\mathrm{H}-\mathrm{HT}$ & $\begin{array}{l}\text { Neg. } \\
(0.444)\end{array}$ & Pos. (0.584) & Pos. (0.654) & Neg. (0.348) & $\begin{array}{l}\text { Pos. } \\
(0.592)\end{array}$ & $\begin{array}{l}\text { Neg. } \\
(0.332)\end{array}$ \\
\hline AMES & $\begin{array}{l}\text { Neg. } \\
(0.411)\end{array}$ & Neg. (0.224) & Neg. (0.044) & Neg. (0.224) & $\begin{array}{l}\text { Pos } \\
(0.74)\end{array}$ & $\begin{array}{l}\text { Neg. } \\
(0.074)\end{array}$ \\
\hline SkinSen & $\begin{array}{l}\mathrm{Neg} \\
(0.340\end{array}$ & $\operatorname{Neg}(0.256)$ & $\operatorname{Neg}(0.186)$ & Neg (0.414) & $\begin{array}{l}\mathrm{Neg} \\
(0.278)\end{array}$ & $\begin{array}{l}\text { Neg. } \\
(0.278)\end{array}$ \\
\hline $\begin{array}{l}\mathrm{LD}_{50}\left(\mathrm{LD}_{50} \text { of }\right. \\
\text { acute toxicity) }\end{array}$ & $\begin{array}{l}3.211- \\
\mathrm{log} \\
\mathrm{mol} / \mathrm{kg} \\
(222.927 \\
\mathrm{mg} / \mathrm{kg})\end{array}$ & $\begin{array}{l}\text { 3.448-log mol/kg } \\
(171.31 \mathrm{mg} / \mathrm{kg})\end{array}$ & $\begin{array}{l}2.71- \\
\text { logmol/kg } \\
(604.02 \mathrm{mg} / \mathrm{kg})\end{array}$ & $\begin{array}{l}2.38-\text { logmol/kg } \\
(1945.92 \mathrm{mg} / \mathrm{kg})\end{array}$ & $\begin{array}{l}2.58-\mathrm{log} \\
\mathrm{mol} / \mathrm{kg} \\
(737.444 \\
\mathrm{mg} / \mathrm{kg})\end{array}$ & $\begin{array}{l}2.69-\mathrm{log} \\
\mathrm{mol} / \mathrm{kg} \\
(648.262 \\
\mathrm{mg} / \mathrm{kg})\end{array}$ \\
\hline DILI & $\begin{array}{l}\mathrm{Neg} . \\
0.424\end{array}$ & Neg. $(0.196)$ & Pos. 0.904 & Pos. 0.84 & Pos. 0.9 & Pos. 0.9 \\
\hline \multicolumn{7}{|c|}{ Pharmacokinetics } \\
\hline Gl absorption & High & High & High & High & High & High \\
\hline $\begin{array}{l}\text { Log } K_{\mathrm{p}}(\text { skin } \\
\text { permeation) } \\
\mathrm{cm} / \mathrm{s}\end{array}$ & -7.85 & -7.36 & -6.93 & -7.77 & -6.25 & -7.40 \\
\hline
\end{tabular}

From these six, two phytocompounds (vernolide, neoandrographolide, isorhamnetin and luteolin), fulfilled the requirement for at least four from the five physicochemical analysis (Lipinski, Veber, Ghose, Egan and Muegge) analysis, thereby suggesting favourable physicochemical/druggable properties (Table 6) $[47,56]$. Vernolide, expressed positive and high probability of human intestinal absorption and non-substrate to the permeability-glycoprotein (P-gp). It is thereby suggested that the phytocompounds will be absorbed into the blood stream subverting the capability of P-gp to pumps them back into the intestinal lumen, bile ducts, urine-conducting ducts and capillaries respectively [57]. Blood brain barrier (BBB) penetration, predicts the blood brain barrier penetration of a molecule. Vernolide displayed properties that indicated their ability to cross the BBB. SARS-CoV-2 has been reported to infect the brain, thus indicating its ability to cross the blood brain barrier (BBB) [58], compounds that can cross the BBB will be beneficail in the overal all viral clearance. compounds that can cross the BBB will be beneficail in the overall viral clearance. The estimated half-life time 
(less than 2 hours) and clearance ratefall within the moderate range. Vernolide, neoandrographolide, isorhamnetin presented a tolerable $\mathrm{LD}_{50}$ between $(51 \sim 500 \mathrm{mg} / \mathrm{kg})$, Among the descriptors for the in silico toxicities analysis, $h$ ERG channel plays a vital role in the repolarization and termination stages of action potential in cardiac cells [59].

Compounds that block the hERG channel have the potential to cause cardiotoxicity [60]. All the six phytocompounds did not exhibit the potential of being hERG channel blockers, suggesting that they may not cause $h$ ERG channel-related cardiotoxicity. The three compounds did not exhibited mutagenicity in silico, thereby they may notcause genetic mutations, which do initiate the pathophysiology of other diseases, such as cancer. The impact of the compounds on phase I drug metabolism in the liver was also analysed using the various cytochrome P450 descriptors. Vernolide, neoandrographolide did not display inhibitory potential for the various cytochrome P450, thus may not adversely affect phase I drug metabolism in the liver. Hence, vernolide, neoandrographolide seem to demonstrate high probability of absorption, subcellular distribution, and low toxicity. The ADME/tox analysis indicated high aqueous solubility.

\subsection{Molecular Dynamic Simulations and binding free energy calculation for the best two complexes.}

MDS for the best two complexes were performed for 25 ns using NAMD software, and then the MM-GBSA was done using Amber tools. In Table 7, the residual contribution for the binding of $3 \mathrm{CL}^{\text {pro }}$ and the best two compounds (Neoandrographolide and Vernolide) are listed with the bold residues for the highest contributed residues in the binding (bold). The active site dyads (H41 and C145) are shown underlined in the table as well. For the 3CL pro_

Neoandrographolide complex, C44 is the main contributor for the binding $(-1.20 \mathrm{kcal} / \mathrm{mol})$, while for the $3 \mathrm{CL}^{\mathrm{pro}-V e r n o l i d e}$ complex, H41, C145, and M165 are the main contributors $(-1.18,-1.00$, and $-1.24 \mathrm{kcal} / \mathrm{mol}$, respectively). The contribution of the active site dyads ( $\mathrm{H} 41$ and $\mathrm{C} 145)$ of the $3 \mathrm{CL}^{\text {pro }}$ in the binding of Vernolide to the protein is evident from Table $7(-2.18 \mathrm{kcal} / \mathrm{mol})$. In comparison, a lower contribution of these two residues was reported in the case of the $3 \mathrm{CL}^{\mathrm{pro}}$ - Neoandrographolide complex $(-0.36 \mathrm{kcal} / \mathrm{mol})$. 
Table 7

The MMGBSA calculations for the best two complexes after 25 ns MDS. Bold residues are that have binding energy greater than or equal to $0.5 \mathrm{kcal} / \mathrm{mol}$.

\begin{tabular}{|c|c|c|c|c|}
\hline \multirow[t]{2}{*}{ complex } & \multicolumn{2}{|c|}{ 3CLpro-Neoandrographolide complex } & \multicolumn{2}{|c|}{ 3CLpro-vernolide complex } \\
\hline & Residue & Binding energy (kcal/mol) & Residue & Binding energy (kcal/mol) \\
\hline & $\mathrm{C} 44$ & -1.20 & M165 & -1.24 \\
\hline & P52 & -0.72 & $\mathrm{H} 41$ & -1.18 \\
\hline & Q189 & -0.69 & C145 & -1.00 \\
\hline & L50 & -0.66 & H164 & -0.91 \\
\hline & N51 & -0.50 & L27 & -0.88 \\
\hline & $\mathrm{R} 188$ & -0.42 & Q189 & -0.36 \\
\hline & S46 & -0.37 & T25 & -0.26 \\
\hline & C145 & -0.26 & C44 & -0.20 \\
\hline & $\mathrm{R} 40$ & -0.25 & V42 & -0.19 \\
\hline & T45 & -0.21 & V186 & -0.19 \\
\hline & $\mathrm{T} 25$ & -0.15 & P39 & -0.18 \\
\hline & G143 & -0.14 & $\mathrm{R} 40$ & -0.18 \\
\hline & V186 & -0.11 & G143 & -0.09 \\
\hline & $\mathrm{H} 41$ & -0.10 & G146 & -0.08 \\
\hline & V42 & -0.09 & F181 & -0.07 \\
\hline & $\mathrm{H} 163$ & -0.09 & D187 & -0.07 \\
\hline & S144 & -0.07 & R188 & -0.06 \\
\hline & M165 & -0.07 & & \\
\hline & $\mathrm{C} 38$ & -0.06 & & \\
\hline & N142 & -0.06 & & \\
\hline tOTAL BINDING ENERGY & $-6.50 \mathrm{kca}$ & /mol & $-8.51 \mathrm{kca}$ & mol \\
\hline
\end{tabular}

Figure 5 supports the previous results when the Root Mean Square Fluctuations (RMSF) in $\AA$ was plotted for the apo-

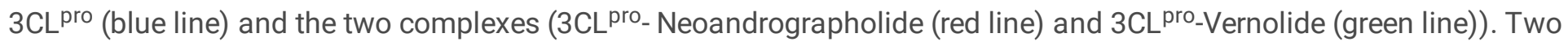
regions of the RMSF plots have higher fluctuations (greater than $2 \AA$ ) in addition to the $N$ and $C$ termini, the S46-P52 region (red cartoon) and the T190-A193 region (yellow cartoon). As shown in the RMSF at the S46-P52 region, the apo-

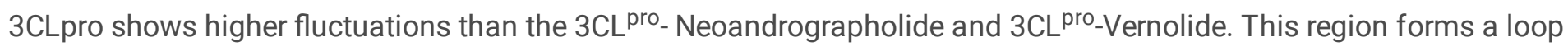
that is important in substrate recognition since its presence near the protein's active site (blue sticks). The stabilization effect of the ligand binding to that region of the protein is due to $\mathrm{C} 44$ (magenta sticks) in the case of $3 \mathrm{CL}^{\text {pro }}$ Neoandrographolide, which has the most contribution in the protein-ligand binding $(-1.20 \mathrm{kcal} / \mathrm{mol})$. In comparison, H41

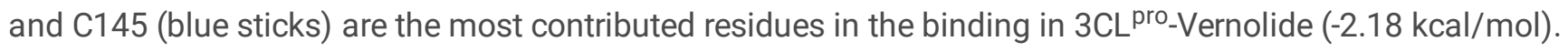




\section{Conclusion}

Ethnopharmacological uses of herbs, spices, and medicinal plants are due to their wide range of biological activities in human health and diseases [61-63]. Among these, Vernonia amygdalina and Occinum gratissimum and their extracts have been extensively reported for their antiviral activities in vitro [19, 20, 22]; and thereby may be suggested as vegetal resources for bioactive compounds for the development of preventive nutraceuticals and drug candidates in COVID-19 infection [23]. Structure-based virtual screening of our in-house library of Vernonia amygdalina- and Occinum gratissimum- derived compounds against $3 \mathrm{CL}^{\text {pro }}$ revealed two drug-like terpenoid structures viz: neoandrographolide and vernolide, alongside other phytochemicals as promising non-covalent inhibitors of SARS-CoV-2 3CL ${ }^{\text {Pro }}$ viz: neoandrographolide and vernolide. These terpenoid structures are accommodated within the substrate-binding pocket, and interacted with the catalytic dyad, the oxyanion loop (residues 138-145), and the S1/S2 subsites of the enzyme active site. With the aid of an array of hydrogen bonds and hydrophobic interactions with residues 142-145, these phytocompounds may stabilize the conformation of the flexible oxyanion loop; and thereby interfere with the tetrahedral oxyanion intermediate formation during proteolytic cleavage. Binding affinity calculation using Molecular Mechanics Generalized Born Surface Area (MM-GBSA) and Root Mean Square Fluctuations (RMSF) analyses using through Molecular Dynamics Simulations (MDS) further revealed that the terpenoid-enzyme complexes exhibit strong interactions and structural stability, which could be adapted for experimental models towards development of preventive nutraceuticals, food supplement, and antiviral drugs in coronavirus diseases.

\section{Declarations}

Acknowledgements: The authors acknowledge with thanks resources offered by the PhytoBioNet platform. MDS and MM-GBSA calculations are done on the Bibliotheca Alexandrina HPC facility, Alexandria, Egypt.

Disclosure statement: No potential conflict of interest is reported by the authors

Funding: This research did not receive any specific grant from funding agencies in the public, commercial, or not-forprofit sectors.

\section{References}

1. C. Liu, Q. Zhou, Y. Li, L.V. Garner, S.P. Watkins, L.J. Carter, J. Smoot, A.C. Gregg, A.D. Daniels, S. Jervey, and D. Albaiu, Research and Development on Therapeutic Agents and Vaccines for COVID-19 and Related Human Coronavirus Diseases, ACS Central Science (2020).

2. H. Wang, X. Li, T. Li, S. Zhang, L. Wang, X. Wu, and J. Liu, The genetic sequence, origin, and diagnosis of SARS-CoV-2, European journal of clinical microbiology \& infectious diseases: official publication of the European Society of Clinical Microbiology 39 (2020), pp. 1629-1635.

3. M. Fani, A. Teimoori, and S. Ghafari, Comparison of the COVID-2019 (SARS-CoV-2) pathogenesis with SARS-CoV and MERS-CoV infections, Future Virology (2020).

4. M. Pal, G. Berhanu, C. Desalegn, and V. Kandi, Severe acute respiratory syndrome Coronavirus-2 (SARS-CoV-2): An update, Cureus 12 (2020).

5. M. Hoffmann, H. Kleine-Weber, S. Schroeder, N. Krüger, T. Herrler, S. Erichsen, T.S. Schiergens, G. Herrler, N.-H. Wu, and A. Nitsche, SARS-CoV-2 cell entry depends on ACE2 and TMPRSS2 and is blocked by a clinically proven protease inhibitor, Cell (2020).

6. L. Zhang, D. Lin, X. Sun, U. Curth, C. Drosten, L. Sauerhering, S. Becker, K. Rox, and R. Hilgenfeld, Crystal structure of SARS-CoV-2 main protease provides a basis for design of improved a-ketoamide inhibitors, Science 368 (2020),

Page $21 / 29$ 
pp. 409-412.

7. M. Shahid, and S. Shahzad-Ul-Hussan, Structural insights of key enzymes into therapeutic intervention against SARS-CoV-2, Journal of Structural Biology (2020).

8. S. Ullrich, and C. Nitsche, The SARS-CoV-2 main protease as drug target, Bioorganic \& medicinal chemistry letters 30 (2020), pp. 127377-127377.

9. G.A. Gyebi, A.P. Adegunloye, I.M. Ibrahim, O.M. Ogunyemi, S.O. Afolabi, and O.B. Ogunro, Prevention of SARS-CoV-2 cell entry: insight from in silico interaction of drug-like alkaloids with spike glycoprotein, human ACE2, and TMPRSS2, J Biomol Struct Dyn (2020), pp. 1-25.

10. B. Cao, Y. Wang, D. Wen, W. Liu, J. Wang, G. Fan, L. Ruan, B. Song, Y. Cai, and M. Wei, A trial of lopinavir-ritonavir in adults hospitalized with severe Covid-19, New England Journal of Medicine (2020).

11. S. Panyod, C.-T. Ho, and L.-Y. Sheen, Dietary therapy and herbal medicine for COVID-19 prevention: A review and perspective, Journal of traditional and complementary medicine 10 (2020), pp. 420-427.

12. S. Gupta, V. Singh, P.K. Varadwaj, N. Chakravartty, A.V.S.K.M. Katta, S.P. Lekkala, G. Thomas, S. Narasimhan, A.R. Reddy, and V.B. Reddy Lachagari, Secondary metabolites from spice and herbs as potential multitarget inhibitors of SARS-CoV-2 proteins, Journal of biomolecular structure \& dynamics (2020), pp. 1-20.

13. A.J. Akindele, F.O. Agunbiade, M.O. Sofidiya, O. Awodele, A. Sowemimo, O. Ade-Ademilua, M.O. Akinleye, I.O. Ishola, and I. Orabueze, COVID-19 Pandemic: A Case for Phytomedicines, Natural Product Communications 15 (2020), p. $1934578 \times 20945086$.

14. K.T. Choy, A.Y. Wong, P. Kaewpreedee, S.F. Sia, D. Chen, K.P.Y. Hui, D.K.W. Chu, M.C.W. Chan, P.P. Cheung, X. Huang, M. Peiris, and H.L. Yen, Remdesivir, lopinavir, emetine, and homoharringtonine inhibit SARS-CoV-2 replication in vitro, Antiviral Res 178 (2020), p. 104786.

15. A. Pandey, M.K. Khan, M. Hamurcu, and S. Gezgin, Natural Plant Products: A Less Focused Aspect for the COVID-19 Viral Outbreak, Frontiers in Plant Science 11 (2020).

16. G.A. Gyebi, O.B. Ogunro, A.P. Adegunloye, O.M. Ogunyemi, and S.O. Afolabi, Potential inhibitors of coronavirus 3chymotrypsin-like protease (3CL(pro)): an in silico screening of alkaloids and terpenoids from African medicinal plants, Journal of biomolecular structure \& dynamics (2020), pp. 1-13.

17. G.O. Igile, W. Oleszek, M. Jurzysta, S. Burda, M. Fafunso, and A.A. Fasanmade, Flavonoids from Vernonia amygdalina and their antioxidant activities, Journal of Agricultural and Food Chemistry 42 (1994), pp. 2445-2448.

18. I.T. Oyeyemi, A.A. Akinlabi, A. Adewumi, A.O. Aleshinloye, and O.T. Oyeyemi, Vernonia amygdalina: A folkloric herb with anthelminthic properties, Beni-Suef University Journal of Basic and Applied Sciences 7 (2018), pp. 43-49.

19. D. Nittya, and K. Suresh, A review on ethno-medicinal uses and pharmacology of Vernonia cinerea Less, Natural product research 29 (2014), pp. 1-16.

20. M.K. Oladunmoye, O. Afolami, B. Oladejo, I.A. Amoo, and B. Osho, Derivatized Extracts from Aframomium melegueta K. Schum. and Vernonia amygdalina Delile Contain Organic Compounds that Showed Antiviral Effects against Atypical Fowl Pox Virus (FPV Kabete), Journal of Antivirals and Antiretrovirals 11 (2020).

21. B.J. Oso, and O.M. Ogunyemi, Assessment of in vitrobiological properties of aqueous extracts of Murraya koenigii(L.) Spreng, Thymus vulgaris L.,and Ocimum gratissimum L. leaves, Croat. J. Food Sci. Technol. 12 (2020), p. DOI: 10.17508/CJFST.2020.12.2.13.

22. S. Pandey, S. Singh, N. Kumar, and R. Botany, ANTIVIRAL, ANTIPROTOZOAL, ANTIMALARIAL AND INSECTICIDAL ACTIVITIES OF OCIMUM GRATISSIMUM L, Asian Journal of Pharmaceutical Research and Development 5 (2017), pp. 1-9.

23. G.N. Bongo, A. Matondo, C. Mbadiko Mutunda, C. Inkoto, E. Lengbiye, C. Kabengele, D. Tshibangu, D. Tshilandaa, K.T.-N. Ngbolua, and P.T. Mpiana, Ocimum Species as Potential Bioresources against COVID-19: A Review of Their

Page $22 / 29$ 
Phytochemistry and Antiviral Activity, International Journal of Pathogen Research 5 (2020), pp. 42-54.

24. C.O. Esimone, O. Omobuwajo, C. Amadi, M.U. Adiku, R. Edrada-Ebel, and C. Chaidir, Antiviral potentials of Nigerian aframomum melagueta Roscoe and Piper guineense Schum. and Thonn, Nigerian Journal of Natural Product and Medicine 10 (2006), pp. 51-54.

25. Prevention of SARS-CoV-2 cell entry: insight from in silico interaction of drug-like alkaloids with spike glycoprotein, human ACE2, and TMPRSS2, Journal of biomolecular structure \& dynamics (2020), pp. 1-25.

26. L.S. Borquaye, E.N. Gasu, G.B. Ampomah, L.K. Kyei, M.A. Amarh, C.N. Mensah, D. Nartey, M. Commodore, A.K. Adomako, P. Acheampong, J.O. Mensah, D.B. Mormor, and C.I. Aboagye, Alkaloids from Cryptolepis sanguinolenta as Potential Inhibitors of SARS-CoV-2 Viral Proteins: An In Silico Study, BioMed Research International 2020 (2020), p. 5324560.

27. E.H.B. Maia, L.C. Assis, T.A. de Oliveira, A.M. da Silva, and A.G. Taranto, Structure-Based Virtual Screening: From Classical to Artificial Intelligence, Frontiers in Chemistry 8 (2020).

28. N.M. O'Boyle, M. Banck, C.A. James, C. Morley, T. Vandermeersch, and G.R. Hutchison, Open Babel: An open chemical toolbox, J Cheminform 3 (2011), p. 33.

29. O. Trott, and A.J. Olson, AutoDock Vina: improving the speed and accuracy of docking with a new scoring function, efficient optimization, and multithreading, J Comput Chem 31 (2010), pp. 455-61.

30. H. Berman, K. Henrick, and H. Nakamura, Announcing the worldwide Protein Data Bank, Nat Struct Biol 10 (2003), p. 980.

31. COVID-19 main protease with unliganded active site, http://www.rcsb.org/structure/6Y84, 2020.

32. S. Jo, T. Kim, V.G. Iyer, and W. Im, CHARMM-GUI: a web-based graphical user interface for CHARMM, Journal of computational chemistry 29 (2008), pp. 1859-1865.

33. J.C. Phillips, R. Braun, W. Wang, J. Gumbart, E. Tajkhorshid, E. Villa, C. Chipot, R.D. Skeel, L. Kale, and K. Schulten, Scalable molecular dynamics with NAMD, Journal of computational chemistry 26 (2005), pp. 1781-1802.

34. W. Humphrey, A. Dalke, and K. Schulten, VMD: visual molecular dynamics, J Mol Graph 14 (1996), pp. 33 - 8, 27 - 8.

35. P. Mark, and L. Nilsson, Structure and dynamics of the TIP3P, SPC, and SPC/E water models at $298 \mathrm{~K}$, The Journal of Physical Chemistry A 105 (2001), pp. 9954-9960.

36. E.F. Pettersen, T.D. Goddard, C.C. Huang, G.S. Couch, D.M. Greenblatt, E.C. Meng, and T.E. Ferrin, UCSF Chimera-a visualization system for exploratory research and analysis, Journal of computational chemistry 25 (2004), pp. $1605-1612$.

37. S. Jo, T. Kim, V.G. Iyer, and W.J.J.o.c.c. Im, CHARMM-GUI: a web-based graphical user interface for CHARMM, 29 (2008), pp. 1859-1865.

38. B.R. Brooks, C.L. Brooks III, A.D. Mackerell Jr, L. Nilsson, R.J. Petrella, B. Roux, Y. Won, G. Archontis, C. Bartels, and S.J.J.o.c.c. Boresch, CHARMM: the biomolecular simulation program, 30 (2009), pp. 1545-1614.

39. J. Lee, X. Cheng, J.M. Swails, M.S. Yeom, P.K. Eastman, J.A. Lemkul, S. Wei, J. Buckner, J.C. Jeong, Y.J.J.o.c.t. Qi, and computation, CHARMM-GUI input generator for NAMD, GROMACS, AMBER, OpenMM, and CHARMM/OpenMM simulations using the CHARMM36 additive force field, 12 (2016), pp. 405-413.

40. B.R. Miller III, T.D. McGee Jr, J.M. Swails, N. Homeyer, H. Gohlke, A.E.J.J.o.c.t. Roitberg, and computation, MMPBSA. py: an efficient program for end-state free energy calculations, 8 (2012), pp. 3314-3321.

41. D.S.C. D.A. Case, T.E. Cheatham, III, T.A. Darden, R.E. Duke, T.J. Giese, H. Gohlke, A.W. Goetz, D., N.H. Greene, S. Izadi, A. Kovalenko, T.S. Lee, S. LeGrand, P. Li, C. Lin, J. Liu, T. Luchko, R. Luo, K.M.M. D. Mermelstein, G. Monard, H. Nguyen, I. Omelyan, A. Onufriev, F. Pan, R. Qi, D.R. Roe, A., C.S. Roitberg, C.L. Simmerling, W.M. Botello-Smith, J. Swails, R.C. Walker, J. Wang, R.M. Wolf, X., and L.X. Wu, D.M. York and P.A. Kollman, AMBER 2017, University of California, San Francisco, (2017). 
42. G.M. Morris, R. Huey, W. Lindstrom, M.F. Sanner, R.K. Belew, D.S. Goodsell, and A.J. Olson, AutoDock4 and AutoDockTools4: Automated docking with selective receptor flexibility, J Comput Chem 30 (2009), pp. 2785-91.

43. M.D. Hanwell, D.E. Curtis, D.C. Lonie, T. Vandermeersch, E. Zurek, and G.R. Hutchison, Avogadro: an advanced semantic chemical editor, visualization, and analysis platform, Journal of cheminformatics 4 (2012), p. 17.

44. J. Fliege, and B.F. Svaiter, Steepest descent methods for multicriteria optimization, Mathematical Methods of Operations Research 51 (2000), pp. 479-494.

45. A.K. Rappe, C.J. Casewit, K.S. Colwell, W.A. Goddard, and W.M. Skiff, UFF, a full periodic table force field for molecular mechanics and molecular dynamics simulations, Journal of the American Chemical Society 114 (1992), pp. 10024-10035.

46. S. Salentin, S. Schreiber, V. Haupt, M. Adasme, and M. Schroeder, PLIP: Fully automated protein-ligand interaction profiler, Nucleic acids research 43 (2015).

47. A. Daina, O. Michielin, and V. Zoete, SwissADME: a free web tool to evaluate pharmacokinetics, drug-likeness and medicinal chemistry friendliness of small molecules, Scientific reports 7 (2017), p. 42717.

48. F. Cheng, W. Li, Y. Zhou, J. Shen, Z. Wu, G. Liu, P.W. Lee, and Y. Tang, admetSAR: a comprehensive source and free tool for assessment of chemical ADMET properties, J Chem Inf Model 52 (2012), pp. 3099-105.

49. A. Trezza, D. Iovinelli, A. Santucci, F. Prischi, and O. Spiga, An integrated drug repurposing strategy for the rapid identification of potential SARS-CoV-2 viral inhibitors, Scientific reports 10 (2020), pp. 1-8.

50. H. Yang, M. Yang, Y. Ding, Y. Liu, Z. Lou, Z. Zhou, L. Sun, L. Mo, S. Ye, H. Pang, G.F. Gao, K. Anand, M. Bartlam, R. Hilgenfeld, and Z. Rao, The crystal structures of severe acute respiratory syndrome virus main protease and its complex with an inhibitor, Proc Natl Acad Sci U S A 100 (2003), pp. 13190-5.

51. Z. Jin, X. Du, Y. Xu, Y. Deng, M. Liu, Y. Zhao, B. Zhang, X. Li, L. Zhang, and C. Peng, Structure of M pro from SARSCoV-2 and discovery of its inhibitors, Nature (2020), pp. 1-5.

52. J.Y. Li, Z. You, Q. Wang, Z.J. Zhou, Y. Qiu, R. Luo, and X.Y. Ge, The epidemic of 2019-novel-coronavirus (2019-nCoV) pneumonia and insights for emerging infectious diseases in the future, Microbes Infect 22 (2020), pp. 80-85.

53. J. Wang, Fast identification of possible drug treatment of coronavirus disease-19 (COVID-19) through computational drug repurposing study, Journal of Chemical Information and Modeling (2020).

54. H.-x. Su, S. Yao, W.-f. Zhao, M.-j. Li, J. Liu, W.-j. Shang, H. Xie, C.-Q. Ke, H.-c. Hu, M.-n. Gao, H. Liu, J.-s. Shen, W. Tang, L. Zhang, G.-f. Xiao, L. Ni, D.-w. Wang, J.-P. Zuo, and Y.-c. Xu, Anti-SARS-CoV-2 activities in vitro of Shuanghuanglian preparations and bioactive ingredients, Acta Pharmacologica Sinica 41 (2020).

55. Z. Jin, Y. Zhao, and Y. Sun, Structural basis for the inhibition of SARS-CoV-2 main protease by antineoplastic drug carmofur, 27 (2020), pp. 529-532.

56. C.A. Lipinski, Drug-like properties and the causes of poor solubility and poor permeability, J Pharmacol Toxicol Methods 44 (2000), pp. 235-49.

57. J.H. Lin, and M. Yamazaki, Role of P-glycoprotein in pharmacokinetics, Clinical pharmacokinetics 42 (2003), pp. 5998.

58. L. Zanin, G. Saraceno, P.P. Panciani, G. Renisi, L. Signorini, K. Migliorati, and M.M. Fontanella, SARS-CoV-2 can induce brain and spine demyelinating lesions, Acta Neurochirurgica (2020), pp. 1-4.

59. E. Raschi, V. Vasina, E. Poluzzi, and F. De Ponti, The hERG K + channel: target and antitarget strategies in drug development, Pharmacological research 57 (2008), pp. 181-195.

60. J.M. Kratz, U. Grienke, O. Scheel, S.A. Mann, and J.M. Rollinger, Natural products modulating the hERG channel: heartaches and hope, Natural product reports 34 (2017), pp. 957-980.

61. C.O. Olaiya, M.I. Choudhary, O.M. Ogunyemi, and A.B. Nwauzoma, Nutraceuticals from Bitter Leaf (Vernonia amygdalina Del.) Protects against Cadmium Chloride induced Hypertension in Albino Rats, Nature and Science 11 
(2013), pp. 136-145.

62. G.A. Gyebi, J.O. Ocheje, and O.M. Ogunyemi, Molecular docking studies on bioactive compounds from clove (Syzygium Aromaticum) on metabolic regulators in cancer, Salem University Journal of Life Sciences 1 (2019), pp. 1-18.

63. O.M. Ogunyemi, A.G. Gyebi, J.O. Adebayo, J.A. Oguntola, and C.O. Olaiya, Marsectohexol and other pregnane phytochemicals derived from Gongronema latifolium as a-amylase and a-glucosidase inhibitors: in vitro and molecular docking studies, SN Applied Sciences 2 (2020), p. 2119.

\section{Figures}

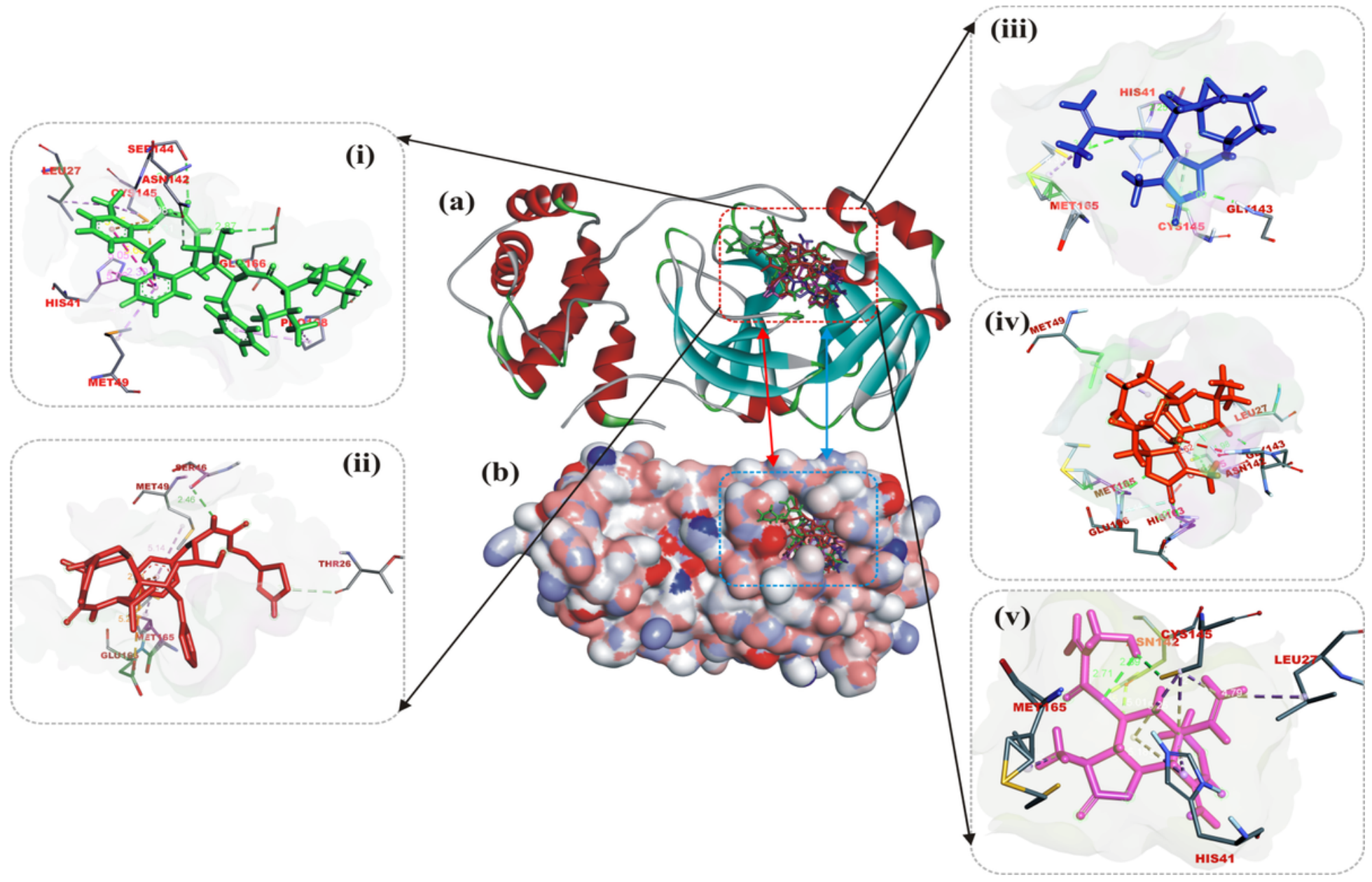

Figure 1

Views of interactions of representative top binding phytochemicals with amino acids in the active site of 3-Chymotrypsinlike protease of SARS-CoV-2 3CLpro. Ligands in stick representation are presented in different colours: (a) Green: Lopinavir (b) Red: Ritonavir (c) Blue: Vernolide (d) Orange: Isorhamnetin (e) Purple: 11,13-dihydrovernodalin. Types of interactions are represented by: Green-dotted line-hydrogen bonding; light purple-dotted line-hydrophobic interaction (pialkyl, alkyl and pi-stacking); purple-dotted line-pi-pi T-Shaped interaction; light purple-dotted line - pi-stacking interaction yellow-dotted line-pi-sulphur interaction and 3-letter abbreviation of amino acids are in red colour. 


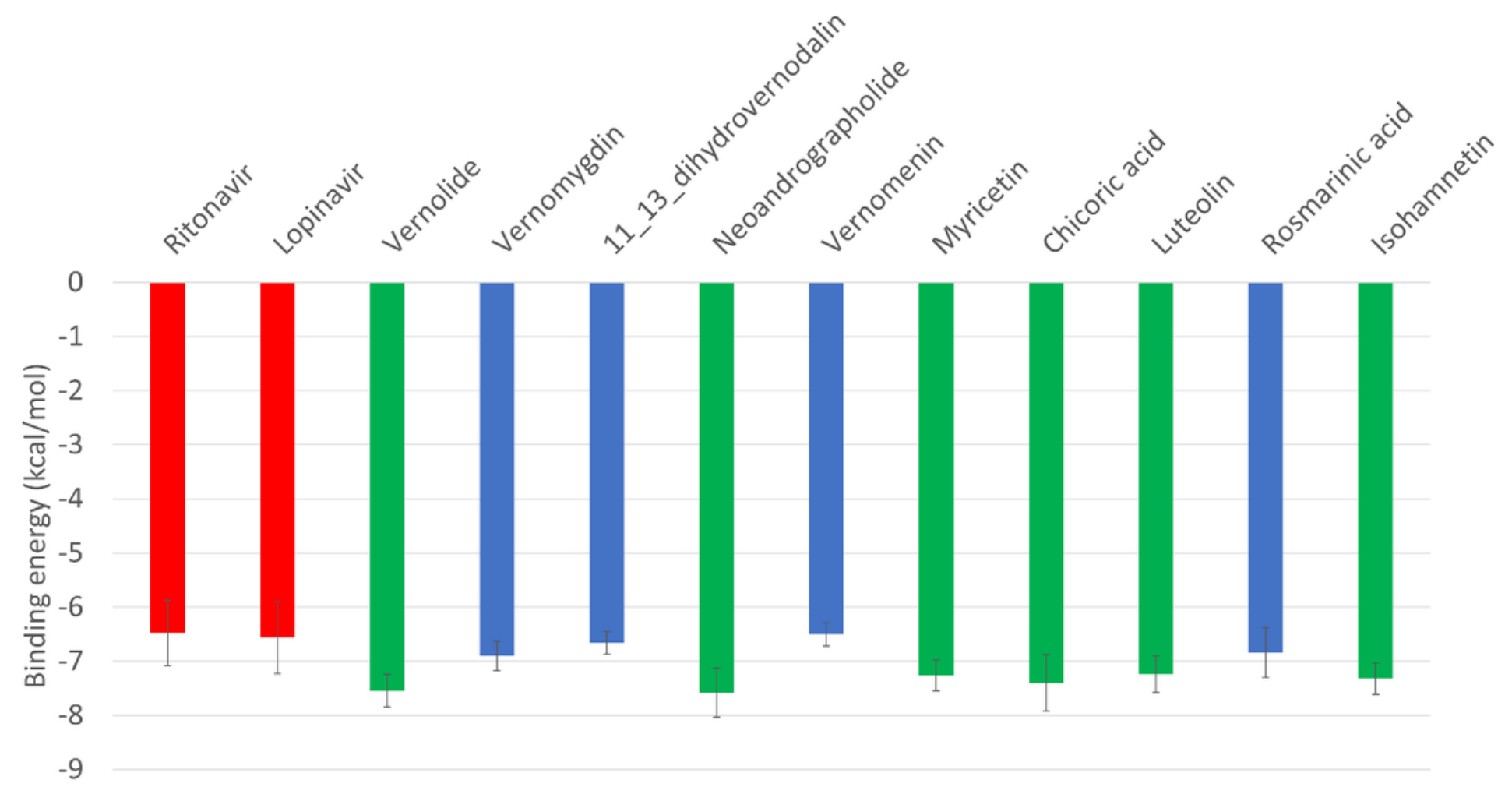

Figure 2

The average binding energy values of the positive controls (Ritonavir and Lopinavir) and the best ten natural compounds calculated with AutoDock Vina software. 


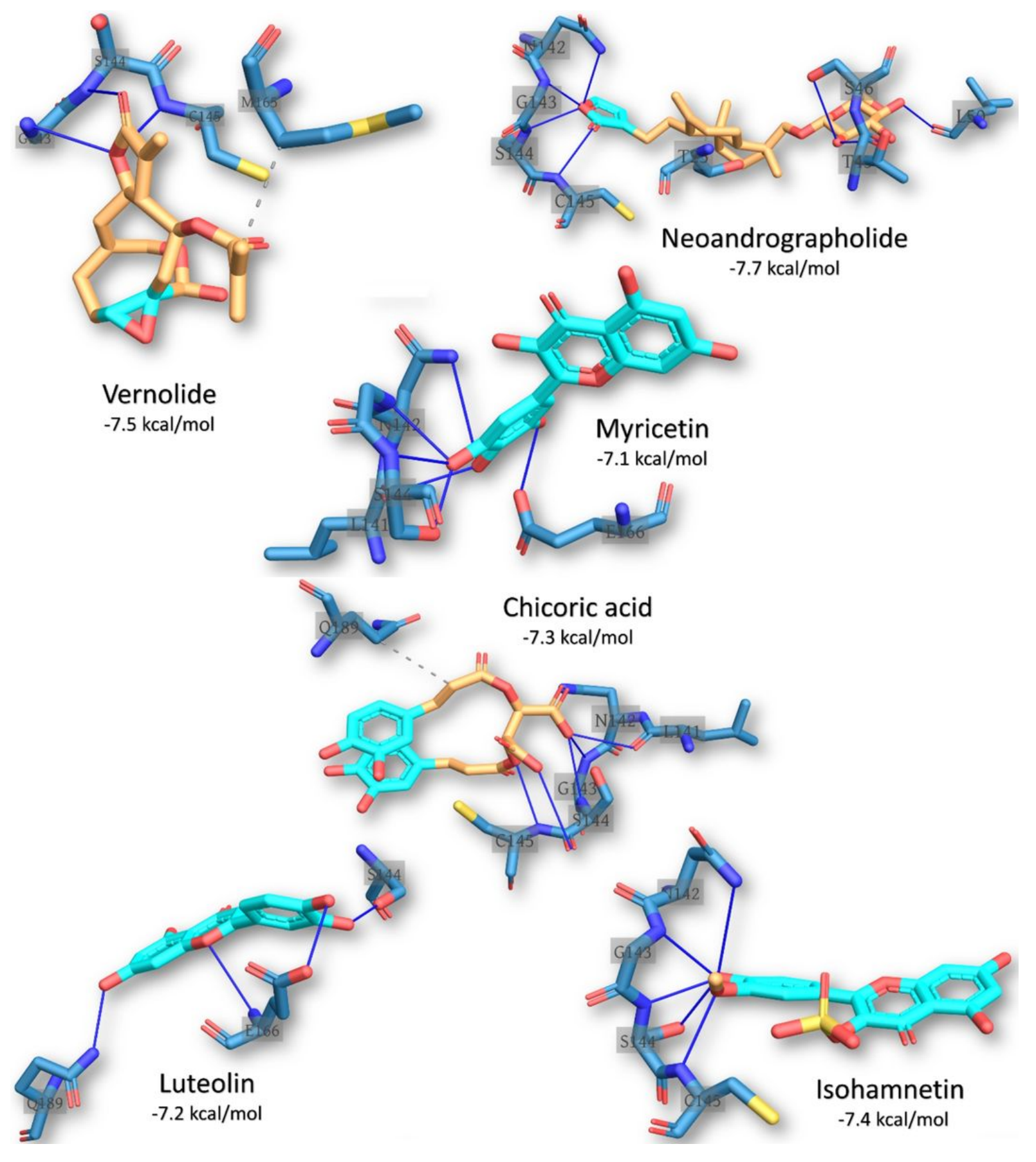

Figure 3

The interaction pattern of the best six phytochemical structures with the active site of the best representative conformation from the cluster analysis of SARS-CoV-2 3CLpro MDS trajectories.. The residues of the 3CLpro are shown in blue sticks labelled by its one-letter code. The ligands are represented in yellow sticks with cyan aromatic rings. $\mathrm{H}$ bonds are shown in blue lines while hydrophobic contacts in dashed-gray lines. 

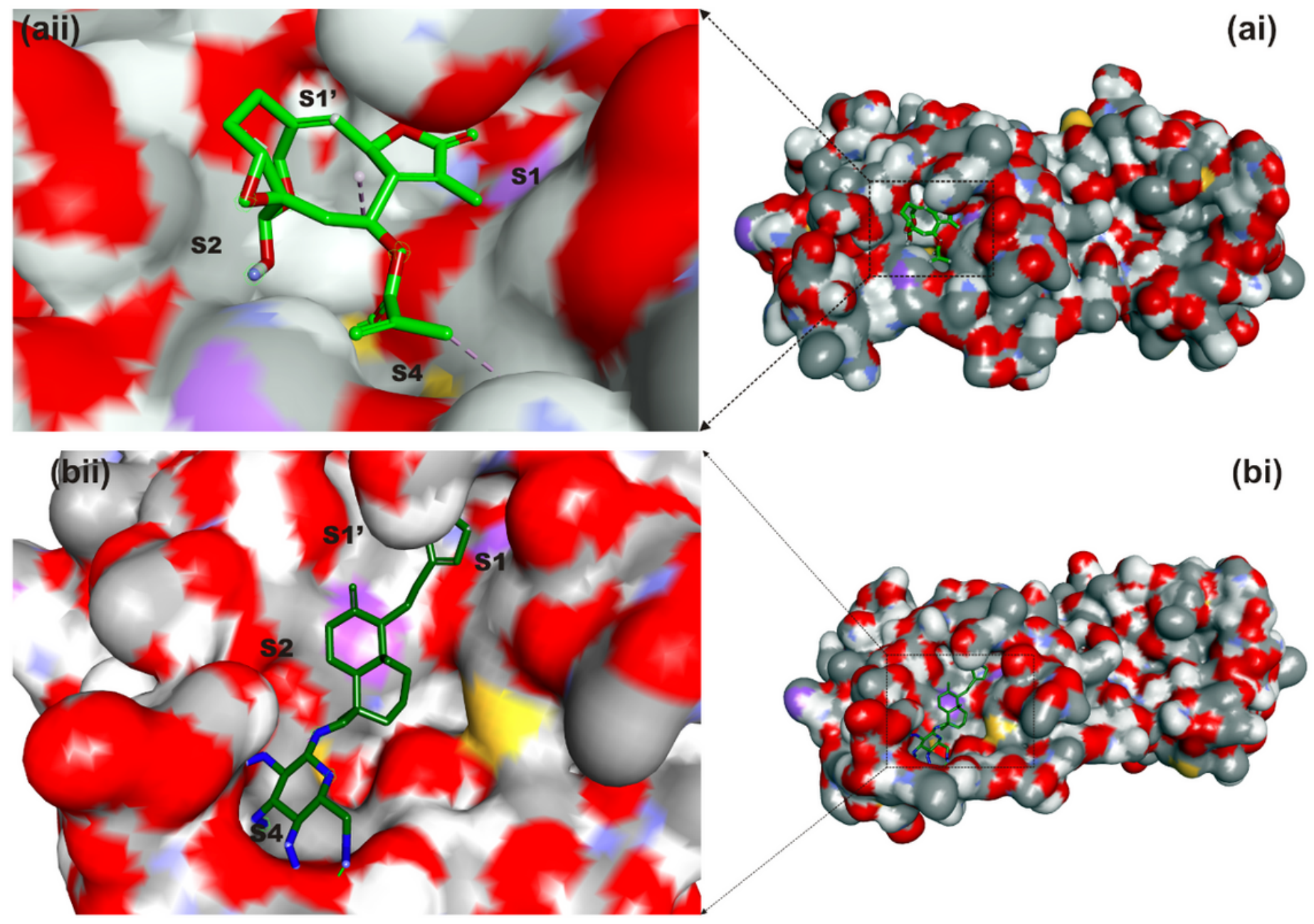

Figure 4

Surface representation of (a) vernolide and (b) neoandrographolide in the substrate-binding pocket of SAR-CoV-2 3CLpro. 


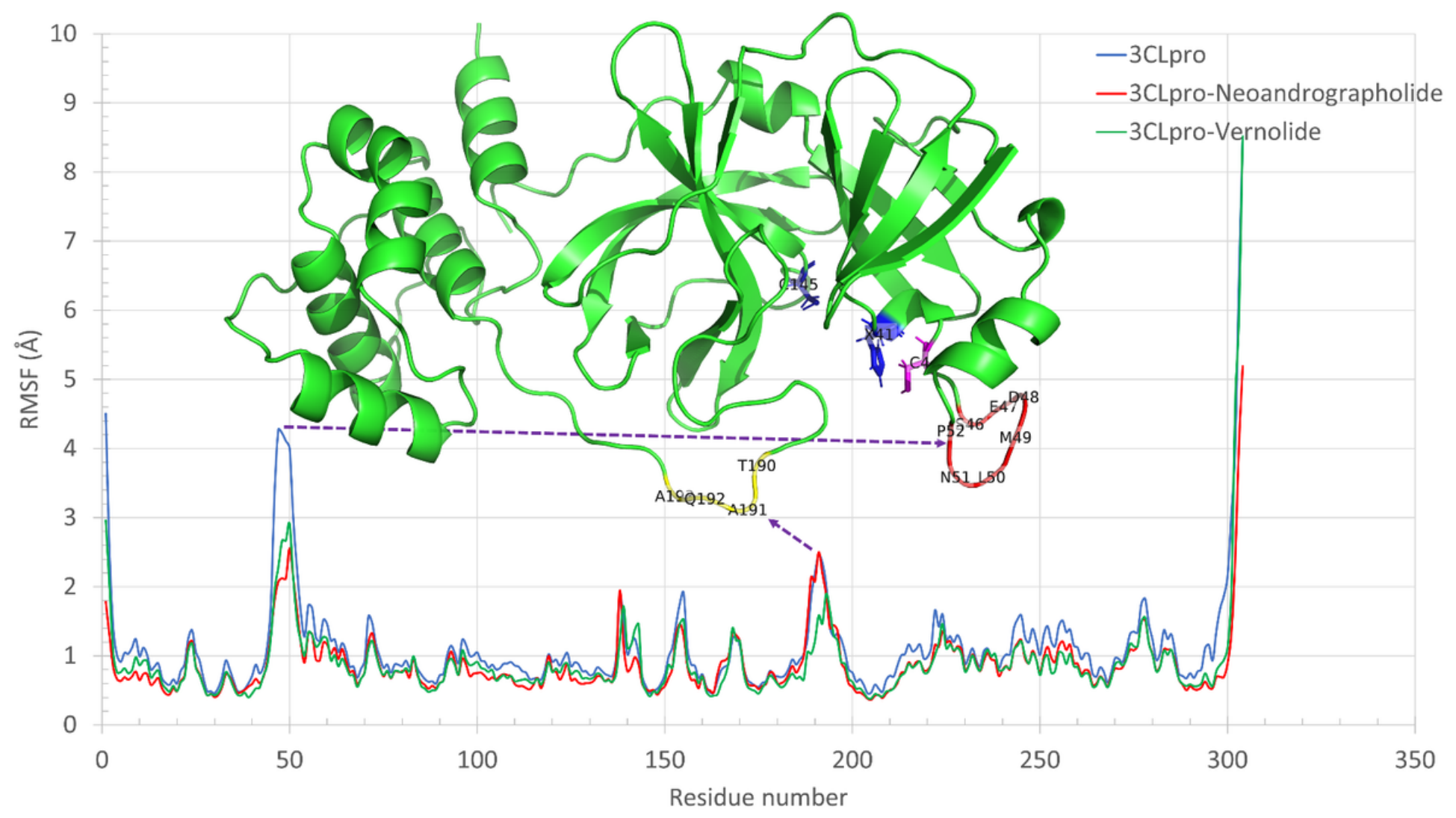

Figure 5

The per-residue RMSF calculated for the apo-protein (blue), 3CLpro-Neoandrographolide (red), and 3CLpro-Vernolide (green). The structure of the protein is represented in a green cartoon with some residues in coloured sticks.

\section{Supplementary Files}

This is a list of supplementary files associated with this preprint. Click to download.

- NewSupplementary.docx 